Florida International University FIU Digital Commons

\title{
The Buddhist Coleridge: Creating Space for The Rime of the Ancient Mariner within Buddhist Romantic Studies
}

Katie Pacheco

Florida International University, kpach003@fiu.edu

DOI: $10.25148 /$ etd.FI13080912

Follow this and additional works at: https://digitalcommons.fiu.edu/etd

Part of the Chinese Studies Commons, Christianity Commons, Comparative Methodologies and Theories Commons, Ethics and Political Philosophy Commons, Ethics in Religion Commons, Literature in English, British Isles Commons, Other Arts and Humanities Commons, Other English Language and Literature Commons, Other Languages, Societies, and Cultures Commons, Other Religion Commons, Philosophy of Mind Commons, Practical Theology Commons, and the Religious Thought, Theology and Philosophy of Religion Commons

\section{Recommended Citation}

Pacheco, Katie, "The Buddhist Coleridge: Creating Space for The Rime of the Ancient Mariner within Buddhist Romantic Studies" (2013). FIU Electronic Theses and Dissertations. 937.

https://digitalcommons.fiu.edu/etd/937 


\title{
FLORIDA INTERNATIONAL UNIVERSITY
}

Miami, Florida

\section{THE BUDDHIST COLERIDGE: CREATING SPACE FOR THE RIME OF THE ANCIENT MARINER WITHIN BUDDHIST ROMANTIC STUDIES}

\author{
A thesis submitted in partial fulfillment of \\ the requirements for the degree of \\ MASTER OF ARTS \\ in \\ ENGLISH \\ by
}

Katie Pacheco 


\section{To: Dean Kenneth Furton}

College of Arts and Sciences

This thesis, written by Katie Pacheco, and entitled The Buddhist Coleridge: Creating Space for The Rime of the Ancient Mariner within Buddhist Romantic Studies, having been approved in respect to style and intellectual contents, is referred to you for your judgment.

We have read this thesis and recommend that it be approved.

Heidi Scott

Steven Heine

Maneck H. Daruwala, Major Professor

Date of Defense: June 27, 2013

The thesis of Katie Pacheco is approved.

\begin{tabular}{r} 
Dean Kenneth G. Furton \\
College of Arts and Sciences \\
\hline Dean Lakshmi N. Reddi \\
University Graduate School
\end{tabular}

Florida International University, 2013 


\section{DEDICATION}

I dedicate my thesis to my family and friends, who have supported and encouraged me throughout the entire graduate program. Special thanks to my mother, Caridad Noriega, and best friend, David Atehortua; their constant and unwavering encouragement has given me the push and tenacity to attain goals that seemed unreachable. 


\section{ACKNOWLEDGMENTS}

I would like to thank my committee members for guiding me through the thesiswriting process. Dr. Heidi Scott was a fine outside reader, and her useful comments pushed me to new insights. Dr. Steven Heine was a constant source of information on the topic of Buddhism, and his prompt and valuable feedback allowed me to bolster and refine my claims. Finally, I am indebted to my major professor, Dr. Maneck H. Daruwala, whose immense patience and generosity have made this thesis possible. Her detailed commentaries, quick eye, and expertise on Romanticism have guided me to write a paper I am truly proud of. 


\begin{abstract}
OF THE THESIS
THE BUDDHIST COLERIDGE: CREATING SPACE FOR THE RIME OF THE ANCIENT MARINER WITHIN BUDDHIST ROMANTIC STUDIES
\end{abstract}

\author{
by
}

Katie Pacheco

Florida International University, 2013

Miami, Florida

\title{
Professor Maneck H. Daruwala, Major Professor
}

The popularization of academic spaces that combine Buddhist philosophy with the literature of the Romantic period - a discipline I refer to as Buddhist Romantic Studies - have exposed the lack of scholarly attention Samuel Taylor Coleridge and The Rime of the Ancient Mariner have received within such studies. Validating Coleridge's right to exist within Buddhist Romantic spheres, my thesis argues that Coleridge was cognizant of Buddhism through historical and textual encounters. To create a space for The Rime within Buddhist Romantic Studies, my thesis provides an interpretation of the poem that centers on the concept of prajna, or wisdom, as a vital tool for cultivating the mind. Focusing on prajna, I argue that the Mariner's didactic story traces his cognitive voyage from ignorance to enlightenment. By examining The Rime within the framework of Buddhism, readers will also be able to grasp the importance of cultivating the mind and transcending ignorance. 


\section{TABLE OF CONTENTS}

CHAPTER

PAGE

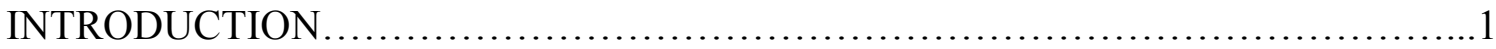

I. THE MARINER AS OTHER -

THE MARGINALIZATION OF THE RIME OF THE ANCIENT MARINER FROM BUDDHIST ROMANTIC STUDIES............................... 8

II. THE DHARMA BLOSSOMS IN EUROPE A SHORT REVIEW OF HISTORICAL AND TEXTUAL CONNECTIONS BETWEEN COLERIDGE AND BUDDHISM..................................31

III. THE MARINER'S SUTRA ON PRAJNA A BUDDHIST APPROACH TO THE MARINER'S COGNITIVE JOURNEY FROM IGNORANCE TO ENLIGHTENMENT...............................52

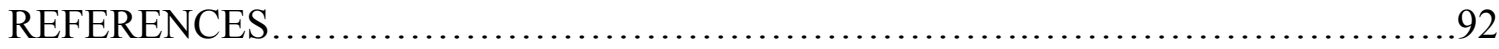




\section{INTRODUCTION}

"Drive my dead thoughts over the universe

Like withered leaves to quicken a new birth!

And, by the incantation of this verse,

Scatter, as from unextinguished hearth

Ashes and sparks, my words among mankind!

Be through my lips to unawakened Earth

The trumpet of a prophecy!”

-Percy Bysshe Shelley, "Ode to the West Wind"1

As a long-time adherent and frequent attendant of Wat Buddharangsi of Miami, ${ }^{2}$ reading Samuel Taylor Coleridge's The Rime of the Ancient Mariner within the vein of Buddhism did not initially seem like an aberration to me. I first encountered the poem as a college freshman, and my mind at the time could not conceive of The Rime as being anything other than a Buddhist poem. The Mariner's ego-based slaying of the albatross, and the suffering he encounters afterward, mirrored the Buddha's teachings on The Four Noble Truths; ${ }^{3}$ the environmental response following the death of the albatross highlighted the Buddhist doctrine of Conditioned Genesis; ${ }^{4}$ and the cognitive

${ }^{1}$ The Norton Anthology of English Literature, vol. 2, ed. M.H. Abrams, p. 732, 63-69.

${ }^{2}$ Wat Buddharangsi of Miami practices Theravada Buddhism, which is "the oldest of the three major vehicles of Buddhism. Its ideal figure is the arhat, or enlightened monastic scholar, as opposed to the ideal figure of Mahayana and Vajrayana, the bodhisattva" (Maguire 244).

${ }^{3}$ The Four Noble Truths teach: "(1) life is suffering, (2) suffering is caused by craving, (3) suffering can have an end, and (4) there is a path which leads to the end of suffering" (Keown 48).

${ }^{4}$ The doctrine of Conditioned Genesis asserts: "nothing in this world is absolute. Everything is conditioned, relative, and interdependent" (Rahula 53). 
transformation the Mariner undergoes pointed at a spiritual journey similar to that experienced by the historical Buddha.

When I confidently raised my hand high during class and offered the literature professor my Buddhist analysis of The Rime, his reply swiftly shot me down like the arrow that struck and killed Coleridge's albatross. He disapprovingly bellowed, "Coleridge was not a Buddhist, and the Mariner is not a Buddha figure, he is the Wandering Jew! The Rime of the Ancient Mariner is a Christian poem about sin and redemption.” Silenced by rejection, I wrote my term paper that semester on the spiritually castigated Mariner/Wandering Jew instead of on the enlightened Mariner/Buddha.

It was not until graduate school that the desire to read Coleridge within the philosophical framework of Buddhist thought re-engendered itself. Giving in to my scholarly thirst, I defiantly decided I would 'Buddha-dize' the Mariner for my Master's thesis. Whenever I verbalized my intent, I was often asked the same three questions by professors and peers regarding the validity and purpose of such a pursuit: (1) "Has anyone else analyzed The Rime of the Ancient Mariner - or Coleridge - within the vein of Buddhism?” (2) "Was Coleridge even familiar with Buddhism?" and (3) "What new insights into the poem would a Buddhist reading bring?" Because I heard these questions habitually, they became the guide and fuel for my study. Therefore, each of the three chapters present within the thesis is dedicated to answering the above research questions.

Chapter 1 addresses the first research question by examining the manner in which five sources represent and analyze Coleridge within the framework of Buddhist philosophy - a scholarly trend I refer to throughout the thesis as Buddhist Romantic Studies. The works chosen for analysis are R.H. Blyth's Zen in English Literature and 
Oriental Classics, John G. Rudy's Romanticism and Zen Buddhism, Mark S. Lussier's Romantic Dharma: The Emergence of Buddhism into Nineteenth-Century, John Drew's India and the Romantic Imagination, and Antonella Riem Natale's The One Life: Coleridge and Hinduism. These particular works were selected because they make up the only scholarly work I was able to uncover dedicated to Coleridge within the framework of Buddhism. ${ }^{5}$ Although Blyth, Rudy, Lussier, Drew, and Natale all engage themselves in a dialogue concerning the role Buddhism plays within Coleridge's poems, their research also works to unveil the miniscule role The Rime has been allowed to play within Buddhist Romantic Studies, for not only is very little attention devoted to The Rime, the little that does exist is terse and largely undeveloped. The overall goal of Chapter 1 is to expose the lack of scholarly attention Coleridge and The Rime have received within Buddhist Romantic Studies.

Coleridge's marginalization within the academic arena of Buddhism is puzzling given his familiarity with the religion, and Chapter 2 highlights that discrepancy by surveying Coleridge's cognizance of Buddhism through historical and textual encounters. Historically, Coleridge and his family, as well as all of $19^{\text {th }}$ century Europe, have been linked to India - the birthplace of Buddhism; it is likely these personal encounters led Coleridge to inquire on the religions practiced within that region. Coleridge was also a prolific reader, and researchers and scholars (as well as Coleridge's own journals and marginal notes) have documented Coleridge as having read a variety of texts that would have exposed him to the different sects of Buddhism practiced throughout the world. As a

\footnotetext{
${ }^{5}$ In Romanticism and Zen Buddhism, John G. Rudy acknowledges the lack of attention Coleridge has received within Buddhist Romantic Studies: "Unlike Blake, Coleridge has occasioned less attention from the Zen Buddhist community" (251).
} 
consequence of his reading works by Sir William Jones, Marco Polo, and Samuel Purchas, Coleridge would have been familiar with Theravada, Mahayana, and Vajrayana Buddhism $^{6}$ (although it is unlikely he would have known Buddhism by these names). For the purpose of justifying Coleridge's inclusion within Buddhist Romantic Studies, Chapter 2 argues that Coleridge was familiar with Buddhism, and thus, a Buddhist reading of any of his poems would not serve as an academic aberration. Despite Coleridge's cognizance of Buddhism, it is not the aim of this study to prove that Coleridge purposely and meticulously imbued The Rime of the Ancient Mariner with Buddhist concepts. It is solely to show that those elements of Buddhism are in fact there in order to open up a space for The Rime of the Ancient Mariner within academic discourses.

To begin the movement of creating a space for The Rime within Buddhist Romantic Studies, Chapter 3 provides an interpretation of the poem that centers on the concept of prajna, or wisdom. Prajna is defined as the "generation of penetrating and critical insight," which gradually develops through meditation, resulting in an awakening to nirvana ${ }^{7}$ (Keown 98). Focusing on prajna (or the lack thereof), Chapter 3 argues that the Mariner's didactic story traces his cognitive voyage from ignorance to enlightenment

\footnotetext{
${ }^{6}$ Mahayana, or "great vehicle," is "a major branch of Buddhism that arose during the first century C.E. in opposition to the more conservative Theravada ('way of the elders') branch" (Maguire 238). Vajrayana translates to " "diamond vehicle'; one of the three major vehicles of Buddhism and the one prevailing in Tibet, other regions of the Himalayas, and Mongolia [...]. It evolved out of Mahayana and retains the same body of scriptures and belief in the bodhisattva ideal. However, it also incorporates many of the magical and visionary elements of ancient Indian spirituality" (Maguire 245).

${ }^{7}$ Contrary to popular belief, nirvana is not a state of being, but rather, it is simply reality and truth itself. When one achieves nirvana, one sees everything as it truly is (Rahula).
} 
(i.e., from an ignorant being to a Buddha). As an unawakened being, the Mariner perceives the natural environment as inferior to himself, and he fuels his own self-made concept of inferiority in order to solidify his own existence. The ignorant, ego-based desire to aggrandize the self becomes the impetus for the great suffering the Mariner experiences. Despite the lack of prajna displayed by the Mariner at the beginning of the poem, after a moment of intense meditation, the ego-based self created by the Mariner dissolves, and he becomes an all-seeing, compassionate Buddha who delays nirvana for the sake of ending suffering for all sentient beings. While the objective of Chapter 3 is to focus on prajna in order to make sense of the cognitive transformation the Mariner undergoes, Buddhist concepts themselves are interconnected, interrelated, and codependent, and therefore, the chapter pulls from other Buddhist concepts, as well as Buddhist philosophy and literature, in order to bolster the noteworthy role prajna plays within The Rime.

By focusing on the Mariner's perception of nature as a measure for intelligence (and ignorance), Chapter 3 contributes to the reflection on current issues dealing with environmental and animal rights, for a Buddhist reading of The Rime of the Ancient Mariner brings attention to our current environmental crisis by implicitly urging readers to reflect on their own views toward the natural world, and how those views have contributed to the demise of nature, resulting in extreme weather changes that kill millions of people yearly. Interpreting the poem within a Buddhist context also encourages readers to view the killing of animals and the destruction of nature as a grave wrong, one that will have environmental consequences, which will eventually lead to the demise of the human race. Most importantly, a Buddhist reading of the poem places the 
power of action in the hands of the Mariner; he has the ability to end universal suffering by transcending the disillusion of his own mind. As the Mariner acts on his own newgained knowledge in order to end suffering for all sentient and insentient beings, readers might be encouraged to do the same.

Although Coleridge wrote many versions of The Rime, Chapter 3 exclusively quotes passages from the 1817 edition from Sibylline Leaves using Martin Wallen's Coleridge's Ancient Mariner: An Experimental Edition of Texts and Revisions 17981828. The 1817 edition from Sibylline Leaves was chosen because Coleridge - as discussed in Chapter 2 - continued to be exposed to Buddhism-related texts after the first composition of The Rime. It is likely that those later texts may have influenced Coleridge's revisions. Additionally, the 1817 edition was the last version to experience such drastic changes, and it is also the version most often referenced by scholars.

Written with the determination of bringing a Buddhist reading of The Rime of the Ancient Mariner into English literary circles, this thesis imagines an audience who may not be fully versed in Buddhist concepts and philosophies. Throughout the study, explanations of Buddhist terms and concepts are provided via footnotes. Additionally, it is important to mention here that the emphasis chosen - which highlights the Mariner's cognitive evolution from ignorant to enlightened being - is only one out of many approaches a Buddhist reading of The Rime might engender, particularly since many different sects of Buddhism exist; for this thesis, I have pulled from all three vehicles, ${ }^{8}$ but I have made the topic manageable by limiting my scope to the concept of prajna. My hope is that this thesis will serve as an utterance on behalf of The Rime in order for louder

\footnotetext{
${ }^{8}$ Theravada, Mahayana, and Vajrayana are referred to as the three vehicles of Buddhism.
} 
and more frequent dialogues to emerge on the subject. May this thesis function as "ashes and sparks" (Shelley 67) for the re-ignition of scholarly interest in the Buddhist Coleridge. 


\section{THE MARINER AS OTHER - \\ THE MARGINALIZATION OF THE RIME OF THE ANCIENT MARINER FROM BUDDHIST ROMANTIC STUDIES}

"No man was ever yet a great poet, without being at the same time a profound philosopher."

-Samuel Taylor Coleridge, Biographia Literaria ${ }^{9}$

The emergence of the dharma ${ }^{10}$ in the West - revealed by the growing interest in Buddhist practices and beliefs adopted by non-Eastern people - has given way to the flowering of the dharma within modern literary studies. In consequence of the blooming interest, an abundance of scholarly work has surfaced that aims to reinterpret a wide array of writers within the philosophical framework of Buddhist thought. Despite the many Buddhism-inspired literary texts that have come to light, no literary period in English literature has been reanalyzed within the Buddhist context more frequently than the Romantic period. The growing interest in unveiling the Buddhist philosophy embedded within the works of the Romantic poets has led to the advent of academic courses that explore the connections between Romanticism and Buddhism, as well as the inclusion of a volume titled "Romanticism and Buddhism" in the Romantic Circles Praxis Series - a widely respected scholarly website dedicated to the study of the Romantic period. Along with these major developments in modern literary studies, an abundance of books and articles currently exist that examine the role of Buddhism in Romantic literature, with more texts on the subject being published yearly. From the perspective of Buddhism, the

\footnotetext{
${ }^{9}$ Biographia Literaria; or, Biographical Sketches of My Literary Life and Opinions, vol. 2., ed. J. Shawcross, ch. XV, p.19.

${ }^{10}$ In Buddhism, dharma has multiple definitions depending on the context in which it is used (Rahula). Within the context of spreading dharma, I am referring specifically to the Buddha's teachings.
} 
poetry of William Blake, John Keats, Percy Bysshe Shelley, and William Wordsworth has taken on a different hue - one that highlights the Buddhist concepts of silent meditation, compassionate wisdom, interconnectedness, and emptiness. Such reinterpretations allow scholars to breathe new life into old works - an idea that very much correlates with the spirit of Romanticism, where the mundane and everyday is looked upon with new, childlike excitement.

Despite the scholarly trend, there remains one influential author from the age of Romanticism who has not yet experienced such rejuvenation to the extent that his counterparts have. Excluding such an essential figure of the Romantic period has created a gap within Buddhist Romantic Studies. The deficiency can be attributed to the lack of attention given to Samuel Taylor Coleridge in general and The Rime of the Ancient Mariner in particular. The marginalization of Coleridge and The Rime of the Ancient Mariner from such spheres is baffling, for biographers and scholars have proven that Coleridge extensively studied Eastern literature, philosophy, and religion. Additionally, Coleridge's works seem more heavily imbued with Oriental themes and images than many of his Romantic counterparts, which highlight both the importance and necessity of Coleridge's inclusion within Buddhist Romantic Studies. Despite the unique angle Buddhism lends to a reading of The Rime of the Ancient Mariner, the marginalization of Samuel Taylor Coleridge from discourses involving Romanticism and Buddhism can be seen from the beginning of such studies.

One of the first scholars to critically examine Coleridge within the vein of Buddhism in an extensive study is R.H. Blyth with his 1942 publication of Zen in English Literature and Oriental Classics. In his 435-page book, Blyth tersely alludes to Coleridge 
nine times, whereas Wordsworth is discussed fifty-seven times, not including the chapter that is dedicated solely to Wordsworth. ${ }^{11}$ The degree of attention given to Coleridge, visà-vis the attention given to Wordsworth, unveils the minuscule role Coleridge plays within Blyth's analysis of Romanticism and Buddhism. It is not surprising that he dedicates such little attention to the poet, for throughout the text Blyth criticizes Coleridge's ability to fully comprehend both religion and poetry - subjects Coleridge wrote on extensively throughout his lifetime. According to Blyth, "Coleridge is another of those on the black list, partly for insincere imitation of Wordsworth, partly for his own native lack of religion and poetry" (8). In accordance with Blyth's assessment, since Coleridge does not understand religion, he consequently cannot grasp the philosophical complexities of Buddhist thought.

In order to substantiate his claim that Coleridge belongs on the periphery of Buddhism and Romanticism, Blyth juxtaposes the ending of The Rime of the Ancient Mariner with a haiku written by Taigi: ${ }^{12}$

Symbolism, pantheism, mysticism, religiosity, these are not Zen. Zen is poetry. Compare Coleridge's milk and water, wishy-washy: 'He prayeth best who loveth best / The things both great and small, / For the good God who loveth us, / He made and loveth all' with a real religious poem by Taigi. (Blyth 247)

The purpose of Blyth's comparison here is to bolster his assertion that Coleridge's work lacks the spirit of Zen because of its "wishy-washy" nature. However, what is most problematic about Blyth's rejection of Coleridge is that he does not explain nor clarify

\footnotetext{
${ }^{11}$ See Chapter 17, "Wordsworth."

${ }^{12}$ Blyth's translated passage by Taigi reads, "Not a single stone / To throw at the dog, - / The wintry moon!"' (248).
} 
what he means by the term "wishy-washy." Consequently, readers cannot determine why exactly the Mariner's message is "wishy-washy," or why the presence of such wishywashiness would automatically eliminate the above passage from Zen spheres.

In addition to what Blyth describes as the overly simplistic nature of the above passage, Blyth's rejection of Coleridge also stems from his belief that the message conveyed by the Mariner is pantheistic in nature rather than Buddhist. Blyth's exclusion of Coleridge on the grounds of pantheism seems a bit contradictory, particularly since Wordsworth - whose poetry is quite pantheistic in nature - is given much attention and praise in Blyth's study. ${ }^{13}$ Although Blyth is correct in identifying the pantheism inherent in the passage by Coleridge, he does not acknowledge that Buddhism and pantheism do share similar viewpoints, and consequently, the presence of the latter perspective does not necessarily negate the existence of the former.

Revealing that Buddhism and pantheism can co-exist without contradiction, Thomas McFarland in Coleridge and the Pantheist Tradition reconciles the two viewpoints by referring to the Buddha as a "pantheist" (60). McFarland's supposition is not a farfetched one, for

Pantheism believes that all things are linked in a profound unity. All things have a common origin and a common destiny. All things are

\footnotetext{
${ }^{13}$ Blyth's complete rejection of Coleridge and acceptance of Wordsworth is problematic, particularly since the composition of The Rime of the Ancient Mariner was initially a joint project between Coleridge and Wordsworth. Wordsworth's influence is seen throughout the poem. For example, Wordsworth suggested the killing of the albatross (which he took from Shelvock's Voyages), the idea that the Mariner should be punished for the crime, and the reanimation of the shipmates' dead bodies (Holmes). Additionally, Wordsworth admitted to providing Coleridge with the weathered image of the Mariner and the child-like description of the wedding guest (Holmes). Wordsworth also contributed a few lines to the poem (Fry).
} 
interconnected and interdependent. In life and in death we are an inseparable part of unity, and in realizing this we can find our joy and peace. (Harrison 2)

The above explanation of pantheism provided by Paul A. Harrison in Elements of Pantheism reverberates the Buddhist sentiments of suffering $(d u k k h a)^{14}$ and interconnectedness. According to Buddhist philosophy, in awakening to the true nature of things, one can escape dukkha. Consequently, it is because of ignorance - in failing to see things as they truly are - that people suffer; the failure to realize truth is the greatest hindrance to the "joy and peace" Harrison refers to. Similar to pantheist philosophy, which often highlights happiness and calmness in the realization of unity, Buddhism also attempts to transcend the dualistic, hierarchal mode of thinking that gives way to the false belief that a sovereign and separate 'I' exists; Buddhists believe that illusory, discriminatory beliefs lead to suffering. In labeling the above moment in The Rime of the Ancient Mariner as purely pantheistic - and not Buddhist - Blyth bypasses how the narrator's message at the end of the poem also conveys the Buddhist idea of interconnectedness, for God is described as equally loving all things without discrimination.

Although the message conveyed by the Mariner does reference a creator God which Buddhists do not believe in - in order to emphasize oneness, it is important to mention that the presence of God does not negate a Buddhist reading of the poem. According to Anne Mellor in English Romantic Irony, The Rime of the Ancient Mariner

\footnotetext{
${ }^{14}$ In What the Buddha Taught, Rahula argues that the word "dukkha" is difficult to translate into English. Consequently, there are several English definitions attached to "dukkha," such as "unsatisfactoriness" (Rahula 18). For more interpretations of "dukkha," see Chapter 2 of What the Buddha Taught.
} 
is imbued with both Western (Christian) and Eastern (non-Christian) viewpoints. ${ }^{15}$ The wavering between different religious beliefs is especially disclosed in the passage Blyth quotes, for not only does Coleridge present a God who has created all things, he also presents a God who cannot discern a difference between nature and humans - such a belief goes against the human-centered Christian perspective that posits animals were created for human consumption. ${ }^{16}$ With Christian and non-Christian viewpoints working side-by-side within The Rime of the Ancient Mariner, one cannot reject the presence of a particular viewpoint (Buddhism) on the basis of the concomitant existence of an opposing viewpoint (Christianity).

Despite Blyth's rejection of the Mariner's comment from Buddhist Romantic Studies, he does provide readers with an interpretation of the poem that allows for the beginning of discourses on Coleridge and Zen Buddhism. In his two-page analysis of The Rime of the Ancient Mariner, Blyth compares one particular moment in part VI of the poem with "Not the Wind, Not the Flag" $" 17$ from the Platform Sutra in order to illustrate that the Mariner's perception of the outer world is influenced by his own (and Coleridge's) inner state of mind. For Blyth, the calmness the Mariner experiences when he says, "The moonlight steeped in silentness the steady weathercock" (qtd. in Blyth 160)

\footnotetext{
${ }^{15}$ Mellor's argument is discussed in more depth in Chapter 2.

${ }^{16}$ The connection between anthropocentricism and Christianity, as well as how the poem undermines such views, is discussed further in Chapter 3.

17 "Not the Wind, Not the Flag" is a Zen koan. The koan reads: "At a certain time a flag was blowing about in the wind. One monk said, 'The wind is moving'; another said, 'The flag is moving,' and quarreling was endless. Enô (the $6^{\text {th }}$ patriarch) said, 'The wind is not moving, the flag is not moving; what is moving is your minds"” (qtd. in Blyth 161).
} 
is indicative of the Mariner's momentarily tranquil state of mind.$^{18}$ According to Blyth, "It was the mind of the Ancient Mariner, the mind of Coleridge that was steeped in silentness, that was moonlit, that was steady" (161). Similarly, Blyth posits that when the Mariner states, "The darkness steeps in turbulence the whirling weather-cock"19 (qtd. in Blyth 161), the darkness is not a quality the outer environment possesses, for "moonlight is neither silent nor noisy" (160). Blyth's analysis here is significant, for he begins to touch upon how one key component of Zen Buddhism - non-dualism - can work within The Rime of the Ancient Mariner as a theoretical framework for honing in on the interconnected relationship the Mariner and the natural environment share; such an idea is central to Chapter 3 of the thesis.

Although Blyth's analysis on non-dualism is extremely valuable to this research, in terms of cementing The Rime of the Ancient Mariner within Buddhist Romantic Studies, Blyth's analysis does not create sufficient space for the poem, for he concentrates solely on two obscure moments in the poem. In order to truly offer a Zen interpretation of the poem, how the concepts of non-dualism and interconnectedness play out throughout the most crucial, edifying moments in the poem must be considered such as when the Mariner slays the albatross, when the Mariner's shipmates suddenly die, or when the Mariner spontaneously blesses the water snakes. Not including these

\footnotetext{
${ }^{18}$ Although Blyth does not specify what edition or line he is referencing for his quotations of The Rime of the Ancient Mariner, he appears to be quoting lines 482-483 of the 1817 edition of the poem.

${ }^{19}$ It is not clear what edition Blyth is quoting the above verse from, for "The darkness steeps in turbulence the whirling weather-cock" is nowhere to be found in the 1798 , 1800, or 1817 editions of The Rime of the Ancient Mariner.
} 
moments in a Zen reading of the poem is comparable to overlooking - in a Freudian reading of Hamlet - the closet scene where Hamlet zealously assails his mother and questions her sexuality and virtue. ${ }^{20}$ The Rime of the Ancient Mariner is notorious for its message against the harming of nature, a concept that is conveyed through the killing of the albatross and the domino effect that occurs thereafter. The poem's didactic value lies in the spiritual awakening the Mariner undergoes once he blesses the water snakes and transcends his previously ignorant view of the world. Because these moments are what drive the overall message of interconnectedness to the forefront, they must be reflected upon in order to truly analyze the poem within the vein of Buddhism.

In addition to not exploring the poem in depth, Blyth's analysis seems to be more within the realm of ecocriticism rather than Buddhism. In order to avoid contradicting myself here, it is important to acknowledge that many of the ideas governing ecocritical theory are in direct alignment with Buddhist philosophy. Simon C. Estok articulates the connections between Buddhism and ecocriticism in "Discourses of Nation, National Ecopoetics, and Ecocriticism in the Face of the US" when he describes American ecocriticism as consisting of "American versions of Taoist and Buddhist ecological precepts" (85). Greg Garrard reverberates the sentiment in Ecocriticism by stating that the very "notion of ecocriticism has proceeded from the belief systems derived from Eastern religions such as Taoism and Buddhism" (qtd. in Britto 721).

Further solidifying the significant role Buddhist philosophy plays within ecocritical theory, renowned ecocritic Tim Morton uses Buddhist philosophy several

\footnotetext{
${ }^{20}$ See Act 3, Scene 4 of Hamlet. Also see Ross C. Murfin's "Psychoanalytic Criticism and Hamlet."
} 
times throughout his texts as an instrument for deconstructing intellectual-based notions of nature. In Ecological Thought, Morton pulls from the Tibetan Buddhist concept of emptiness - although he refers to it as "space" - to praise the non-discursive, allembracing mind of the enlightened:

Tibetan culture and religion is all about space [...]. One image of enlightened mind is that it's like space. One Buddhist system says that our Universe, along with a billion universes like it, floats within a single pollen grain inside an anther on a lotus flower growing out of a begging bowl in the hands of a Buddha called Immense Ocean Vairochana. Tibetans would arrive at the edge of the Solar System and declare, 'Wow, what a great opportunity to learn more about emptiness.' (27)

For Morton, it is with an empty, spacious mind that one must look upon nature. To gaze upon nature with a spacious, non-discriminatory mind would allow for the collapse of viewpoints that separate humans from the natural environment. Morton further emphasizes the importance of moving beyond the discursive mind in Ecology without Nature by quoting the founder of Shambhala, ${ }^{21}$ Chögyam Trungpa Rinpoche: “...We are not particularly seeking enlightenment or the simple experience of tranquility ${ }^{22}-$ we are trying to get over our deception" (138). Transcendence from ignorance is the goal of both ecocriticism and Buddhism.

Despite these similarities, in order to comprehend how Blyth offers readers an ecocritical interpretation - rather than a purely Buddhist one - it is imperative to first define ecocriticism. According to Glotefelty and Fromm in The Ecocriticism Reader, "ecocriticism is the study of the relationship between literature and the physical

${ }^{21}$ Pure Land, a sect of Buddhism.

${ }^{22}$ According to Rudy's analysis of "The Eolian Harp" in "Coleridge in Mokusho," Sarah warns the speaker that he must move beyond the attachment to tranquility and emptiness. 
environment" (xviii), and it endeavors to rise above the ingrained dualism of humans and the ecological 'other.' Further exposing the interconnectedness of Buddhism and ecocriticism, Laurence Coupe in The Green Studies Reader quotes John G. Rudy in Wordsworth and the Zen Mind in order to bolster his definition of ecocriticism.

According to Rudy, ecocriticism aims to "realize nature [by moving] beyond duality, beyond the opposition of mind and matter, subject and object, thinker and thing" (qtd. in Coupe 1).

Under these definitions of ecocriticism, an ecocritical or Buddhist reading of any of the Romantic poets would be justified, for the Romantic poets - by and large - were reacting to old perceptions that imagined humans as subjects and animals and nature as objects to be controlled and conquered (Bly). Resembling his counterparts, Coleridge also struggled with pre-Romantic dialectics involving the superiority and separateness of humans from their natural environment, which he expressed in Chapter 22 of Biographia

\section{Literaria:}

During the act of knowledge itself, the objective and subjective are so instantly united, that we cannot determine to which of the two the priority belongs. There is here no first, and no second; both are coinstantaneous and one $[. .$.$] . The existence of things without us, which from its nature$ cannot be immediately certain, should be received as blindly and as independently of all grounds as the existence of our own being, the Transcendental philosopher can solve only by the supposition, that the former is unconsciously involved in the latter; that it is not only coherent but identical, and one and the same thing with our own immediate self consciousness. To demonstrate this identity is the office and object of this philosophy... (qtd. in Coupe 21-22)

Coleridge's philosophical musings, in harmony with Blyth's interpretation of The Rime of the Ancient Mariner, reconcile subject and object by denying any inherent distinction 
between the two binaries, which reverberates the ecocritical and Buddhist concepts of oneness and interrelatedness.

Although a much validated ecocritical approach to The Rime of the Ancient Mariner provides an understanding of the poem that correlates with the Buddhist concept of non-discursive, non-dualistic thinking, Blyth's analysis cannot be labeled as a purely Zen interpretation because it does not go beyond the sole identification of dualistic thinking by focusing on the Buddha-nature inherent in all beings. Blyth's interpretation explains that all things are one, and he uses a koan to support his claim, but he does not explain why all things are one. According to Zen philosophy, the weathercock, the moon, and the Mariner are interconnected because they all possess Buddha-hood. The idea that an inanimate object - such as the weathercock - possesses Buddha-nature is what truly differentiates a Zen interpretation of the poem from an ecocritical one; such an idea also differentiates Mahayana interpretations from other forms of Buddhism, such as Theravada. Although there has been much debate ${ }^{23}$ within Buddhism regarding inanimate or insentient beings and their Buddha-nature, Japanese Zen master Dogen supports the idea that all things are Buddha-nature. According to Masao Abe in A Study of Dogen:

In Dogen's understanding, the Buddha-nature is not a potentiality, like a seed, that exists within all sentient beings. Instead, all sentient beings, or more exactly, all beings, living and nonliving, are originally Buddhanature. It is not a potentiality to be actualized sometime in the future, but the original, fundamental nature of all beings. (42)

The absence of Buddha-nature in Blyth's Zen approach renders his argument more appropriate for ecocritical spheres than Buddhist ones. Although both schools of

${ }^{23}$ See Masao Abe's A Study of Dogen. 
thought would hint at the same message to be learned - that all things are interconnected, Buddhism departs from ecocriticism by placing an emphasis on Buddha-nature as the unifying force for all living and non-living things. Instead of highlighting Buddha-hood, Blyth exclusively evaluates "the nature-culture dualism" (Ambruster and Wallace 4), which is a major critique of ecocriticism. Although Blyth does reference a koan in order to support his ideas surrounding non-dualism, many ecocritical interpretations of literary works - such as those made by Morton - use the same technique to break down "the dialectic between subject and object" (Bate 112). Because of the lack of Buddhist terminology and philosophy used by Blyth in his interpretation, it appears as though he is doing what Morton so often does - using snippets of Buddhist philosophy to support an overall ecocritical approach. Even though Blyth's reading of the poem leans more toward ecocriticism than Buddhism, he is one of the first scholars to explore the role Buddhism plays within Romantic poetry, and as a result, his analysis works as a good start for supporting the argument that The Rime of the Ancient Mariner can be read within the philosophical framework of Buddhism.

Whereas Blyth's interpretation lays the groundwork for the beginning of discourses on Coleridge and Buddhism, John G. Rudy's analysis of "The Eolian Harp"24 - in the chapter titled "Coleridge in Mokusho" 25 in Romanticism and Zen Buddhism allows for the full discussion and inclusion of Coleridge within the domain of Zen. In his

\footnotetext{
${ }^{24}$ Although Rudy does not state what version of "The Eolian Harp" he is using for his analysis, he cites as his source The Poems of Samuel Taylor Coleridge (ed. Ernest Hartley Coleridge, Oxford University Press, 1912).

${ }^{25}$ Mokusho translates to "silent illumination" (Rudy 137).
} 
interpretation, Rudy focuses on non-duality within a Buddhist framework by evaluating the mind's ability to transform perception when it is steadied through the practice of shikantaza ${ }^{26}$ and zazen $^{27}$ - an act the speaker in "The Eolian Harp" achieves. According to Rudy, the meditative speaker of the poem, who sits looking out into nature, is able to break down - through shikantaza and zazen - "visual, emotional, olfactory, and aural sensations $[\ldots]$ in a mode of interanimative communion beyond all efforts to locate the process in a central source" (129). Such non-discursive concentration leads the speaker to cultivate samadhi ${ }^{28}$ - "collectedness of mind, oneness of subject and object" (Rudy 144), which dissolves the separation between speaker and environment by temporarily eradicating the separate and sovereign 'I.' Rudy posits that in the absence of "objective discernment," the speaker happily experiences emptiness, or the absolute, which has a healing effect on him (Rudy 129). However, Sarah's "serious eye” (qtd. in Rudy 146) reminds the speaker that form (or nature) must be perceived as a "path through" the absolute, not "an end to" the absolute (Rudy 147). Sarah's gaze warns the speaker that "one can become attached to emptiness, the experience of oneness, and lose the existential freedom that such experience requires" (Rudy137). Instead of becoming attached to emptiness and tranquility, the speaker must continue to negate "total negation," which results in the process of "Emptiness forever emptying itself" (qtd. in

\footnotetext{
${ }^{26}$ Shikantaza means "just sitting” (Rudy 127).

${ }^{27}$ Zazen is "meditative stillness" (Rudy 127).

28 "Collectedness, one pointed-ness of mind" (Rudy 291).
} 
Rudy 138). Rudy supports his analysis with an extensive use of quotes from distinguished and highly revered Zen masters and teachers, such as Dogen and D.T. Suzuki.

Although Rudy's study allows for discourses on Coleridge and Buddhism by successfully examining how the speaker of "The Eolian Harp" stills the logical mind and dissolves the self through the practice of mediation, Rudy's overall text does not create a space for The Rime of the Ancient Mariner. Although the title-Romanticism and Zen Buddhism - would imply a comprehensive study of the role of Zen Buddhism within Romantic studies, Rudy completely excludes The Rime of the Ancient Mariner - a work that cemented Coleridge as a key figure in the age of Romanticism. Despite its Christian motif, The Rime of the Ancient Mariner can be read within a Zen context using many of the ideas Rudy expanded on for his reading of "The Eolian Harp." For example, the Mariner - like the speaker in "The Eolian Harp" - steadies his own mind through meditation, which allows the Mariner to transcend his own intellectual-based perception of nature. Similar to the tranquil speaker of "The Eolian Harp," the Mariner expresses a great sense of peace in the 'empty' space where duality and isolation do not exist. ${ }^{29} \mathrm{~A}$ Zen-inspired interpretation of this particular moment of the poem would allow for The Rime of the Ancient Mariner to be more fully included into scholarly discussions of Coleridge and Zen Buddhism. In order to create such a space, this study pulls from several insightful connections made by Rudy and reapplies them to The Rime of the Ancient Mariner.

${ }^{29}$ These ideas are expanded upon in Chapter 3. 
In juxtaposition to Rudy, Mark S. Lussier in Romantic Dharma dedicates some space to The Rime of the Ancient Mariner. Nonetheless, like Blyth's succinct coverage of the poem, Lussier only devotes half a page to his analysis. To be fair, unlike the studies conducted by Blyth and Rudy, Lussier's aim is not to reanalyze poetry within the context of Buddhism - although he does dedicate an entire chapter to Blake. ${ }^{30}$ In contrast, his goal is simply to trace the historical and textual expansion of Buddhist philosophy into European consciousness - a significant concept for this study, which I elaborate upon in Chapter 2. As a result, the marginalization of The Rime of the Ancient Mariner-because of a lack of attention - is a byproduct of the author's unique angle of vision rather than a purposeful exclusion.

Where the marginalization of The Rime of the Ancient Mariner occurs within Lussier's piece is in his actual analysis of the poem. In Lussier's Buddhist interpretation of the poem, the Mariner represents the Wandering Jew - a condemned legendary, Christian figure who must wander the earth for eons until he completes penance for his sins against Jesus. Lussier explains,

The Rime of the Ancient Mariner relentlessly explores the experience of individual suffering both in its own poetic terms and through the literary lineage of the work to the myth of the wandering Jew, which establishes the mariner's state of suffering as the result of a divine economy of guilt superimposed by organized religious views of sin, rather than as a boundary condition for all sentient beings, and Coleridge hardens this aspect across his revisions between its initial appearance in Lyrical Ballads and its final state in Sibylline Leaves (through the evocation of Thomas Burnet and the inclusion of the marginal gloss). (67)

${ }^{30}$ See Chapter 5, "Selfhood and Self-Annihilation in Blake's Milton." 
What is problematic about Lussier's interpretation is that it seems to reiterate the already theorized and established Christian view on The Rime of the Ancient Mariner, and as a result, it does not offer a reading that coincides with Buddhist ideology.

Additionally, the legend of the Wandering Jew does not make much sense within a Buddhist framework for the obvious reason that the story of the Wandering Jew is a Christian myth involving Christian biblical figures and events, such as the crucifixion of Jesus. Lussier does not reconcile the problem by making connections between Christianity and Buddhism in order to merit the inclusion of a Christian myth within his Buddhist interpretation of the poem. Moreover, the legend of the Wandering Jew teaches that God himself punished the man who tormented Jesus. The belief in such a God is one unique aspect of Christianity that differentiates it from Buddhism, for Buddhists do not believe in the presence of an almighty creator who dispenses punishments and/or rewards according to deeds. Contrary to Christianity, Buddhists believe in the natural law of karma; ${ }^{31}$ "good karma (kusala) produces good effects, and bad karma (akusala) produces bad effects" (Rahula 32). In order to create a space for The Rime of the Ancient Mariner within Buddhist Romantic Studies, Lussier should not have identified the Mariner as the Wandering Jew of Christian myth. Instead, Lussier could have referenced the law of karma in order to convey a similar interpretation - in the sense that the Mariner suffers for committing an act that causes another sentient being to suffer - sans the Christianity.

Similar to Lussier, who offers readers an interpretation that seems to stray from Buddhism, John Drew - in India and the Romantic Imagination - offers readers an

\footnotetext{
${ }^{31}$ Contrary to what most Westerners believe, karma does not mean the results of an action. Instead, karma literally means volitional "action” or "doing” (Rahula 32).
} 
Indian-inspired approach to "Kubla Khan" under the label of Tantric Buddhism. ${ }^{32}$ With a chapter titled "Coleridge: 'Kubla Khan' and the Rise of Tantric Buddhism," the reader's assumption might be that Drew's aim is to historically and aesthetically analyze the poem within the vein of a particular sect of Buddhism. Instead, Drew's impetus for the chapter seems to be to Indianize Coleridge's poem by exposing all the ways in which "Kubla Khan" and Kublai Khan are connected to India. Drew's unique angle is made clear when he discusses the connection between Tartary and India: "Tartary was indebted to India through Kublai's adoption of Buddhism" (199), and when he posits that Kublai Kahn practiced Indianized Buddhism: "The Mongolian chronicle provides some indication of the sort of Buddhism into which Pakpa would have initiated Kublai. The Indian influences is very strong and Pakpa himself was endowed with Indian titles" (208-209). Although these connections between Coleridge and Buddhism are significant because they validate a Buddhist reading of "Kubla Khan," Drew does not place Buddhism at the center of his analysis. Regardless of the focus taken, the historical and textual connections Drew makes between Coleridge, India, Buddhism, and Kublai Khan are instrumental to this study. Using Drew's valuable work, I expand upon these historical and textual connections in Chapter 2.

However, by linking Coleridge to India, Drew is able to set up his greatest point "Kashmir might be an unnamed objective correlative for the highly-charged interior landscape of 'Kubla Khan'” (Drew 205). By placing Coleridge's "pleasure-dome” (2)

\footnotetext{
${ }^{32}$ Tantric Buddhism is another term for Vajrayana Buddhism.

33 "Kubla Khan," The Norton Anthology of English Literature, vol. 2, ed. M.H. Abrams, p. 440.
} 
within the recesses of Kashmir, Drew moves farther away from Kublai Khan's court and consequently, Tantric Buddhism: "We now turn to Kashmiri mythology to provide a coherent reading of 'Kubla Khan"” (Drew 212). Within the framework of Kashmiri mythology, Drew rejects the influence of Kublai Khan and Tantric Buddhism on Coleridge's imagination: "The dome, as we have seen, Coleridge may have associated directly with Kashmir. The historical Kublai is not said to have built a dome and the association is much more (as indeed highly) likely with the Mughal rulers of India" (Drew 214). By placing Kublai Khan within the margins of his analysis, and Kashmir at the center, Drew connects everything in the poem - the dome, the caves of ice, the Abyssian maid - to Kashmiri myth. Within Drew's Kashmiri framework, the block of ice in the poem becomes "an embodiment of the god Siva" (Drew 215); the river of Xanadu becomes the Indian goddess Parvati, a "complement to Siva on his mountain" (Drew 215).

Although Tantric Buddhists did assimilate Hindu gods into their religion - such as Shiva and Parvati, these gods possess different names and they perform different functions within the context of Buddhism. For example, Avalokitesvara, the bodhisattva of compassion, is the Buddhist embodiment of Shiva (York 122). Shiva is also represented in Buddhism through the half-bird, half-lion image of Sharabha, who makes an appearance as the Buddha in one of his previous lives in the Jataka Tales (Waddell 82). Additionally, within Buddhism, Parvati is portrayed as Tara (Sadasivan 189), who was created from one of the compassionate tears of Avalokitesvara (Huntington and Bangdel 130). In order to remain within the sphere of Buddhism, Drew could have used Shiva and Parvati within his analysis in the same manner in which Buddhists themselves 
represent them - as Avalokitesvara and Tara. Although Drew's emphasis on Kashmir beautifully highlights the important role India and Hinduism have played on Coleridge's imagination, his analysis seems to stray from a purely Buddhist interpretation of "Kubla Khan.”

Contrary to both Lussier and Drew - who mix other viewpoints along with their Buddhist interpretations - in The One Life, Antonella Riem Natale comes closest to creating a niche for Coleridge within Buddhist Romantic Studies. Natale's greatest contribution to this study is the idea - which I elaborate on in Chapter 3 - that the Mariner can be viewed as a Buddha. Despite these moments of "rupture" (Kristeva 2170) where Buddhism and The Rime of the Ancient Mariner converge, Natale's ideas surrounding Buddhism are not always fully explained or elaborated upon, for - just like Lussier - a Buddhist interpretation of Coleridge is outside of Natale's specific scope of Hinduism. Despite the lack of elaboration, those small ruptures of Buddhism throughout Natale's text help to de-marginalize The Rime of the Ancient Mariner from Buddhist Romantic Studies.

Natale's ideas involving Buddhism within the poem start off where Coleridge himself begins - with the Mariner apprehending one of the three wedding guests. Bringing significance to the Mariner's hands, Natale focuses on the hand in conjunction with the Hindu and Buddhist concept of the mudras. In both Hinduism and Buddhism, the mudras represent ritualized movements - particularly hand gestures - that are used during ceremonies; every posture has significance in its symbolic meaning. In reference to Buddha deities, these hand gestures are often seen in paintings and statues. Following her quotation of "skinny hand, so brown" (200) and "I fear thy skinny hand" (200), Natale 
explains: "In Buddhism the closed hand is a symbol of the esoteric secret, and the Buddha is always represented with an open hand, like the Hindu deities, for it unveils the mystery of the existence" (201). Although Natale does not go on to clarify or support her idea within the framework of Buddhism, her quick implication that the Mariner may be a Buddha-like character - on the basis of his hands - raises an interesting possibility.

In spite of the thought-provoking connection between the Mariner and the Buddha, the actual text does not seem to support Natale's assumption that the Mariner's hand is positioned in an "open" manner; instead, the hand is solely described by the narrator as being both "skinny" and "brown" (qtd. in Natale 200). If the Mariner's hand is not positioned in a manner that is indicative of a ritualized message, the mere presence and description of a hand within the poem cannot be interpreted as being symbolic of a mudra. Aside from the fact that the text does not support Natale's interpretation, Natale's ideas lack clarification on what the Mariner's hand gesture signifies, for there are five hand gestures associated with Buddha deities - all conveying a distinct, symbolic message. Although she alludes to the "open hand" position in her interpretation, the implication does not clear up the vagueness of her analysis since there are several positions for the Buddha deities that meet the "open hand" description. There are also several non-Buddha hand gestures that are described as being open-handed; if the Mariner is displaying a non-Buddha mudra, then he cannot be interpreted as a Buddhalike figure solely on the basis of his hand. Without further clarification - and without the text to back up her claim - the hand described by Natale does not fully substantiate her thought-provoking claim that the Mariner is a Buddha. 
Natale again raises the possibility that the Mariner is a Buddha by focusing on the sun and moon in conjunction with the eyes, which are important images in both Hinduism and Buddhism. According to Natale,

[...] the Buddha himself is often defined as the Eye (or Sun) of the World. It is probably a reference to the central or frontal eye, the third all-seeing eye of yogis, focused on the perfect simultaneity of the eternal now. In this triple dimension of Time, the Moon and left eye represent the past, the Sun and right eye the future, and the 'third' eye the everlasting present, that unique and indivisible moment where all other temporal dimensions are fused and transcended. (Natale 178)

The connection Natale makes between the eye and the sun is invaluable to this study, particularly in terms of validating the Mariner as a Buddha figure. Supporting Natale's claim, there are connections between the Mariner's eye and the sun imagery - an idea I expound upon in Chapter 3. Despite the insightful hypothesis, Natale's idea is not elaborated upon or supported, and consequently, Natale's conjuncture can lead to ambiguity. For example, although some Buddhist texts compare the all-seeing Buddha Eye to the sun, the comparison is simply a metaphor for the Buddha's great compassion and omnipotence. A Mahayana sutra highlights the comparison with a simile that describes the Buddha Eye as shining "like a thousand suns" (qtd. in Hua 8). Without further clarification of the Buddha Eye in terms of the sun metaphor, readers might interpret the sun in the poem as representative of the actual Buddha, which would be problematic in a Buddhist reading of the poem.

The unique role the sun plays in The Rime of the Ancient Mariner is what makes a comparison between the sun and the Buddha problematic. Within the context of Natale's argument, the sun - as representative of the Buddha's all-seeing eye - does glare down upon the Mariner; however, the "glaring" down by the sun is described by the narrator as 
a punishment for the Mariner's cruel act against the albatross. Contrary to the peaceful images of the meditative Buddha, within The Rime of the Ancient Mariner the sun is something to be feared, as it is both vengeful and wrathful. Additionally, the Buddha is not a figure who bestows punishments or rewards according to merit. Because of the great suffering the sun causes the Mariner and the shipmates, Natale's analysis seems to distort the role of the Buddha, as well as the meaning behind the all-seeing Buddha Eye.

Although an interesting connection, the text also does not support Natale's description of the sun as "present" and the moon as "past." Looking at all the moments in which the sun is mentioned within the text, there is no indication of these moments being progressive or indicative of the future. The same goes for the moon. Although the moon does play a significant role in Buddhism, particularly the full moon, the symbolic meaning of the moon has nothing to do with the past - at least not for Buddhists. Instead, the significance of the moon in Buddhism lies in the story of the Buddha. According to Venerable K. Sri Dhammananda Maha Thera, "The Buddha was born on a full moon day. His renunciation took place on a full moon day. His Enlightenment, the delivery of His first sermon, His passing away into [nirvana] and many other important events associated with His life-span of eighty years, occurred on full moon days" (para. 1). Although some important moments in the poem occur when the moon is present - such as when the Mariner slays the albatross and when he blesses the water snakes, there are also several important moments that occur when the sun is present - such as when the Mariner encounters the death ship and when the shipmates suddenly die; none of these moments in the poem seem indicative of the past or future. Consequently, Natale's hypothesis is difficult to support when juxtaposed with the actual poem. Despite these moments where 
Natale's arguments seem unsupported or inconsistent with Buddhism, her overall analysis is crucial to this study, for it creates a space that allows for the amalgamation of The Rime of the Ancient Mariner and Buddhism to occur.

Although the studies conducted by Blyth, Rudy, Lussier, Drew, and Natale all involve themselves in a dialogue concerning Buddhism and Coleridge, the connections made between Coleridge and Buddhism within these studies are quite small in scale when compared to the attention that has been given to the other Romantic poets within the framework of Buddhism. Additionally, the studies that do exist barely touch upon The Rime of the Ancient Mariner. Despite the limited coverage given to Coleridge and Buddhism by these scholars, their exploration of Coleridge within the recesses of Buddhism is significant because it forces readers to consider the possibility of reading Coleridge through Buddhist lens. The Rime of the Ancient Mariner - along with the other works in Lyrical Ballads - has contributed to the rise of British Romanticism, and consequently, the exclusion of The Rime of the Ancient Mariner in anything reminiscent of the Romantic period would render such a study incomplete. The gap created by Coleridge's absence from Buddhist Romantic Studies is truly felt, especially since Coleridge, as an inquisitive and "profound philosopher,"34 was not only acquainted with Buddhism, but enthralled by it.

${ }^{34}$ Biographia Literaria; or, Biographical Sketches of My Literary Life and Opinions, vol. 2., ed. J. Shawcross, ch. XV, p. 19. 


\section{THE DHARMA BLOSSOMS IN EUROPE - A SHORT REVIEW OF HISTORICAL AND TEXTUAL CONNECTIONS BETWEEN COLERIDGE AND BUDDHISM}

"Jetzt ist ran nichts als Indiens Sprache und Weisheit die Rede."35

-F.W. J. von Schelling

"In Egypt, Palestine, Greece, and India the analysis of the mind had reached its noon and manhood, while experimental research was still in its dawn and infancy.",36

-Samuel Taylor Coleridge

Perhaps it is a coincidence that the beginning of the Romantic period overlaps with the spread of Eastern religions, such as Buddhism and Hinduism, into Western awareness. The resemblances between the two viewpoints, however, make it difficult to deny the possible influence of Eastern philosophy on the development of what we now consider to be the epistemology of Romantic thought. The Romantic image of the meditative poet - who through quiet contemplation becomes one with his surroundings is in direct alignment with Buddhist philosophy, which teaches that meditation can be used as a means to dissolve dualistic modes of thinking that create a false sense of separation between the self and the natural environment. The desire to transcend a hierarchical view of the world in order to be one with it is a prevalent theme in Samuel Taylor Coleridge's The Rime of the Ancient Mariner. Although the poem is imbued with Buddhist concepts and philosophy, in order to merit a Buddhist reading of The Rime of the Ancient Mariner, the extent of Coleridge's cognizance with Buddhism must be

\footnotetext{
35 "[...] and now we hear of nothing but the language and wisdom of India." Coleridge quotes and responds to the complaint made by Schelling in an 1815 edition of The Friend (Drew 185).

${ }^{36}$ Biographia Literaria; or, Biographical Sketches of My Literary Life and Opinions, vol. 1., ed. J. Shawcross, ch. V, p. 66.
} 
examined. The present chapter offers a short review of the most significant historical events and literary works that may have exposed Coleridge to Buddhism.

For much of Europe, knowledge of the Buddhist religion came as a direct result of "historical encounters and linguistic contacts" between Europe and the Eastern world ${ }^{37}$ (Lussier, "Buddhism and Romanticism" 1107). In "Buddhism and Romanticism," Mark Lussier identifies these significant historical and linguistic events as being the first phases of "punctuated encounters" that eventually led to "the emergence and subsequent reception of Buddhism in European literature and philosophy" ("Buddhism and Romanticism"1107). The British desire to acquire as much knowledge as possible on the Orient led to "textual encounters and conceptual appropriations," events which Lussier describe as being the last phases of Buddhism's journey into Europe ("Buddhism and Romanticism" 1107). These last phases of encounter came as a result of British discovery, circulation, translation, and conceptualization of sacred scriptures and poems in "Pali, Sanskrit, and Tibetan" (Lussier, "Buddhism and Romanticism" 1109) that preceded the Bible, which was before then thought to be the foundation for all knowledge (Natale 11).

With the discovery of these ancient religious texts, Europeans were forced to reexamine their own religious and ethnocentric views while opening their minds to Hindu and Buddhist philosophy and literature (Natale 11). The curiosity expressed by so many did not fail to arouse the young Coleridge's interest and imagination, for as a child he

\footnotetext{
${ }^{37}$ Although Lussier acknowledges that Europeans were first introduced to Buddhism through the story of Alexander the Great's invasion of Asia, he posits that Buddhism was not understood or studied by Europeans until the $18^{\text {th }}$ century ("Buddhism and Romanticism" 1107).
} 
mirrored the society's fascination with the East by cleaving to travel books and sacred texts. As an adult, Coleridge would continue to display a propensity for learning about the East, with an emphasis on religion and philosophy.

Following Lussier's theory of "punctuated encounters" ("Buddhism and Romanticism" 1107), it is likely that Buddhism first made its way into Coleridge's life through the historical encounters between Britain and India. Raymond Schwab makes a similar claim in "The Asiatic Society of Calcutta" by positing that "[ $\mathrm{t}]$ he decisive period in Indic studies began with the arrival of English civil servants in Calcutta around 1780" (31). Serving as civil servants, Coleridge's brothers - John (the eldest of the brothers) and Frank (Coleridge's immediate older brother) - lived in India. Although Coleridge never met John face-to-face, ${ }^{38}$ Coleridge knew his brother through the highly descriptive letters that documented his life in India. It was through these letters that their relationship flourished, and it was through these very same letters that Coleridge might have first become familiar with the Buddhist images that were to later make their way into his works.

One such letter often quoted by Coleridgean scholars is the letter John wrote to William Coleridge in September 29, 1774. Describing a Hindu ritual he witnessed on the Ganges in Monghyr, John writes:

You have no doubt heard of Monghyr famous for its wild romantic situation, and especially for its mountpelier of the East. About 2 miles from the garrison there is a Hotwell in which the water continually boils. The natives esteem it sacred and flock thither from all parts of the Country to receive a holy sprinkling, as they imagine it has the Virtue of cleansing them of their sins. (Engell 32)

\footnotetext{
${ }^{38}$ By the time of Coleridge's birth in 1772 , John had already been deported to India. The two brothers would never meet, for John died of malaria in India in 1787 (Holmes 10).
} 
Although the above passage depicts a Hindu ritual and not a Buddhist one, the description may have exposed Coleridge to Buddhism through the historical context of the described location. While both Hindus and Brahmins deem the Ganges as sacred, the site is also particularly significant for Buddhists because "the Buddha's religious activity was confined to the Gangetic plain" (Huntington 123). According to Antonella Riem Natale in The One Life: Coleridge and Hinduism, "For six years the ascetic Gotama wandered $^{39}$ about the valley of the Ganges, meeting famous religious teachers, studying and following their systems and methods, and submitting himself to rigorous ascetic practices" (Rahula XV). The Buddha was even said to have discovered his "Middle Way" philosophy by watching a boatman tune his instrument ${ }^{40}$ on the Ganges River, which the Buddha later bathed in after breaking away from the extremes of asceticism (Maguire 67). Supporting these historical claims that place the Buddha within the range of the Ganges, many sculptures and images of the Buddha have been uncovered within the

${ }^{39}$ The amount of ground covered by the Buddha was of considerable portion. According to Venerable S. Dhammika, "The area in which the Buddha wandered during his life corresponds roughly to the modern Indian states of Uttar Pradesh and Bihar. The furthermost east he went which can still be identified is Kajangla (now Kankjol, $18 \mathrm{k}$ south of Rajmahal right on the Indo-Bangladesh border) and the furthermost west he is known to have gone is Mathura, some 180 kilometers south of Delhi. These two locations are nearly a thousand kilometers apart. The Buddha's movements northwards were of course limited by the then impenetrable jungles of the Himalayan foothills and it is unlikely that he ever went further south than the southern edge of the Ganges watershed. Still, this would mean that his wanderings covered an area roughly equivalent to 200,000 square kilometers, a huge area by any standards" (para. 4).

${ }^{40}$ The first string of the instrument was wound too tightly and the second string was too loose - neither string provided a sweet sound. Only the third string - neither tight nor loose - made the perfect sound. After observing the instrument, "Siddhartha suddenly realized that the "middle way' of life was the best: neither so austere that existence itself was threatened, nor so sybaritic that one lived selfishly just for pleasure and power" (Maguire 6). 
Gangetic plane. Strengthening the Buddha's ties to the region, the Ganges River also plays a prominent role in several Buddhist texts, such as the Jataka Tales,${ }^{41}$ where many of the stories (e.g., "The Monkey's Heart") take place "in north central India on the Ganges River" (Ashliman).

Seventeen years after John's letter, Frank too would write of the same Ganges area. In his 1791 letter to his mother, Frank expresses a deep veneration for the location. Although Frank does not describe the landscape as John did, Frank does seem to imply that the nature of his admiration is so intense that others may question his national loyalty: "God bless you, best of Parents, tell your Children that their absent Brother is what he ought to be, or if he has one fault it is that of being too Partial to the banks of the Ganges" (qtd. in Engell 95). Frank's 1791 letter was the last he ever sent home, for he died a short while afterward as a result of a gunshot wound he himself delivered while under a fever-induced delirium (Holmes). Because the letter contained the last words Coleridge would ever read from his brother, the mention of the Ganges here - along with the description of its landscape in John's letter - must have solidified in Coleridge's mind the spiritual significance of the Gangetic landscape.

On the basis of what we know about Coleridge and his insatiable appetite for books, it is quite likely that the exotic descriptions of India in John's letter, and the affinity with India expressed by Frank in his letter, would have motivated Coleridge to seek out information on the location; such readings could have unveiled for Coleridge the importance of the Ganges area for Buddhism. Although scholars have not confirmed the

\footnotetext{
${ }^{41}$ The Jataka Tales, or Buddhist birth stories (i.e., from the Buddha's previous lives), are considered the oldest collection of folklore in existence (Babbitt).
} 
above hypothesis, "Kubla Khan" seems to point at the possibility that Coleridge may have recognized the Ganges area as having some connection to Buddhism. The impetus for the hypothesis comes from the popularly held belief that Coleridge may have used the imagery from John's letter as the backdrop for Xanadu (Engell 10), where “the sacred river" (Coleridge 3$)^{42}$ described by Coleridge seems to mimic the holy river depicted in the letter. Moreover, it hardly seems coincidental that the landscape connected to the Buddha is also emphasized in a poem that takes its name after an emperor with "proBuddhist sentiments" (Rossabi 42). The amalgamation of the emperor Kublai Khan with the image of the sacred river in "Kubla Khan" makes it difficult to discredit the possibility of Coleridge's knowledge of Buddhism, as well as the influence his brothers' letters may have had on his reception of Buddhism.

Although "[these letters] could hardly have failed to fire Sam's imagination" (Holmes 10), several other historical events linking Coleridge to India may have also served as motivating factors for Coleridge's later interest in Eastern religions. Concerned with his younger brother's future, in a 1785 letter to James Coleridge, John wrote: "I have been thinking these some days past of getting Sam, a couple of years hence, sent out to me as Cadet at the India House. Let me know your sentiments on this scheme" (qtd. in Holmes 23). Although John's plan would be interrupted by his own untimely death, the possibility of Coleridge living and working in India alongside his brothers must have fueled his desire to learn more about the country's people and customs. Soon after John's death, another important person from Coleridge's circle would make his way to India -

${ }^{42}$ Coleridge's Poetry and Prose, ed. Nicholas Halmi, Paul Magnuson, and Raimonda Modiano, p. 182. 
Thomas Middleton, a childhood friend of Coleridge from Christ's Hospital (Engell). According to Engell in Coleridge: The Early Family Letters, the shock of his brother's death, followed by the absence of a close friend, left Coleridge feeling "lonely and despondent" (12). Four years later, Frank would commit suicide in India (Holmes 23). The life-altering impact of these events must have forever united Coleridge with the idea and image of India; that India was often on his mind is apparent in poems like "The Night Scene" and "Osorio" ${ }^{43}$ (Mazumder), as well as The Rime of the Ancient Mariner. ${ }^{44}$

While "[t]houghts of John, and Frank, far away in India were to have subtle influence on Sam's restless dreams in the future" (Holmes 23), they may have also served as the motivating factor behind Coleridge's interest in folktales that take place in Eastern settings. Coleridge's early enthrallment with Eastern folktales is betrayed through his incessant reading of The Arabian Nights, which he nostalgically described to Thomas Poole - in Oct. 9, 1797 - as having "made so deep an impression on me" (Griggs 347). That Coleridge read, venerated, and was influenced by The Arabian Nights is evident, for the tales had such a "hypnotic power"45 over him that his father, Rev. John Coleridge, "burned the book in hopes of bringing his boy back to earth" (Weissman 110-111). His father's efforts would prove to be futile, for the tales of The Arabian Nights were to

${ }^{43}$ See Mazumder's "Coleridge, Vishnu, and the Infinite" for the connections between these poems and India.

${ }^{44}$ According to Engell, the significance of India on Coleridge's life can be seen in The Rime of the Ancient Mariner, where "The voyage of the Ancient Mariner symbolically traces the sea route to India and the phosphorescence of the Indian Ocean" (9).

${ }^{45}$ In his 1797 letter to Thomas Poole, Coleridge writes, "My father found out the effect, which these books had produced - and burnt them. - So I became a dreamer [...]" (Griggs 208). 
remain forever imprinted within the recesses of Coleridge's mind. Even

[i]n his forties he was still recalling the impact of The Arabian Nights in his essays: '. ..I can never forget with what a strange mixture of obscure dread and intense desire I used to look at the volume and watch it, till the morning sunshine had reached and nearly covered it, when and not before, I felt the courage given me to seize the precious treasure...'(qtd. in Holmes 11)

Adding validity to Coleridge's statements regarding the profound affect the book had on him, in Coleridge's Library: A Bibliography of Books Owned or Read by Samuel Taylor Coleridge, Ralph Coffman documents Coleridge as having owned two versions of The Arabian Nights during the course of his lifetime - a 1778 edition and an 1821 edition (7). Coleridge's reading of The Arabian Nights is significant, for it has several connections to Buddhism, which are unveiled through the 1778 edition's description: "Containing a better account of the customs, manners, and religion of the eastern nations, viz. Tartars, Persians, and Indians, than is to be met with in any Arabian mss. [sic]" (Coffman 7). By reading the 1778 text, Coleridge would have been exposed to numerous Eastern religions and cultures, such as those of China, Iran, and India, and consequently, he would have also been exposed to different sects of Buddhism. While scholars know very little about the making of The Arabian Nights, or the inspiration behind it, scholars have connected it to ancient Sanskrit texts. Ulrich Marzolph supports the above hypothesis in The Arabian Nights: An Encyclopedia: "[...] the frame story of The Arabian Nights relied on various components from Sanskrit texts" (372). Further connecting Buddhism with The Arabian Nights, several scholars ${ }^{46}$ postulate that the

\footnotetext{
${ }^{46}$ See Rhys T.W. Davids' Buddhism Birth: Stories (Jataka Tales) of the Life and Teachings of Gautama the Buddha, Robert Irwin's The Arabian Nights: A Companion, Andrew Skilton's A Concise History of Buddhism, and Ulrich Marzolph's The Arabian
} 
Jataka Tales were the inspiration for many of the stories of The Arabian Nights. For example, in The Arabian Nights: A Companion, Robert Irwin argues that "The Tale of the Merchant and his Wife" and "The Tale of the Bull and the Ass" from The Arabian Nights are found within the "frame stories" of the Jataka Tales (Irwin 65).

Given that Coleridge was an avid reader of The Arabian Nights, it is not surprising that the book's influence ${ }^{47}$ can be found in The Rime of the Ancient Mariner, for there are several similarities between Sinbad the Sailor and the Mariner - which may indicate that Coleridge, whether consciously or subconsciously, took from The Arabian Nights when writing The Rime of the Ancient Mariner. The most blatant resemblance between the two characters is that they are both nomadic seamen whose oceanic adventures are met with a slew of inexplicable, supernatural events. Moreover, both characters behave as educators who must unveil their life experiences to a naïve subject whose role in the text is to provide the sagacious storyteller with the opportunity to tell his edifying tale. Coleridge adds merit to the hypothesis that The Arabian Nights influenced The Rime of the Ancient Mariner when he responds to Anna Barbauld's disapproval of The Rime of the Ancient Mariner on the basis that the tale lacks an overall moral:

It ought to have had no more moral than the Arabian Night's tale of the merchant's sitting down to eat dates by the side of a well, and throwing the shells inside, and Lo! a genie starts up, and says he must kill the

Nights: An Encyclopedia, Vol. 1.

${ }^{47}$ The Arabian Nights also influenced Wordsworth. Wordsworth's enthrallment with The Arabian Nights is captured in The Prelude: "A precious treasure had I long possessed, / A little yellow, canvas-colored book, / A slender abstract of the Arabian tales" (V. 460463). Similarly to both The Arabian Nights and The Rime of the Ancient Mariner, The Prelude showcases a world-traveling seaman. 
aforesaid merchant, because one of the date shells had, it seems, put out the eye of the genie's son. (qtd. in Mellor 149)

In conjunction with The Arabian Nights, there were other "textual encounters" (Lussier, "Buddhism and Romanticism" 1107) during Coleridge's childhood that would have introduced him to Buddhist concepts. In 1785, when Coleridge was only 13 -yearsold, the Bhagavad-Gita ${ }^{48}$ was published, a text which Natale in The One Life posits as having had an impact on "Coleridge's psyche, philosophical approach, and poetical inspiration" (4). However, it is important to mention here that in his later years Coleridge rejects the Bhagavad-Gita through his disapproval of Charles Wilkins' foreword, which compares the Bhagavad-Gita to John Milton. In "Fragment 3" of Coleridge's Opus Maximum, he states,

The translator of the Bagavat Geeta finds in the story of churning the ocean for the fourteen jewels, a wonderful affinity to - Milton! I could not, I confess, [help] inferring from this remark that taste does not resemble the wines that improve from a voyage to and from India. (McFarland 281)

Despite Coleridge's change of sentiment toward the Bhagavad-Gita, what the above passage unveils for scholars is that Coleridge was familiar enough with the text in order to criticize both it and its famous translator.

Further solidifying that Coleridge was familiar with Buddhism, in A History of Sanskrit Literature, A.A. Macdonell asserts that Coleridge read several of the translated

${ }^{48}$ Although the Bhagavad-Gita is considered to be a Hindu text, there are many similarities between the teachings of the Buddha and the philosophy of the BhagavadGita. By reading the Bhagavad-Gita, Coleridge would have been exposed to some of the tenets of Buddhist philosophy. For information on the connections between Buddhism and the Bhagavad-Gita, see Early Buddhism and the Bhagavadgita by Kashi Nath Upadhyaya. Also see pages 97 and 118 of What the Buddha Thought by Richard Gombrich. 
Sanskrit texts that were both published and widely read in Europe during his youth (qtd. in Natale 22). Many of these translations were published in Asiatic Researches, a periodical from The Asiatic Society of Bengal (Drew). Coleridge's outspoken reverence for Jones and Wilkins, both of whom were regularly published in these periodicals, validates that he read these works; for instance, in Opus Maximum, Coleridge recollects how he used to regard the Sanskrit texts translated by Sir William Jones and Charles Wilkins - or the "great linguists" (Muirhead 284), as he called them - "with an almost superstitious awe" (Drew 185). Scholars postulate that Coleridge read other works by Jones aside from those that were published by The Asiatic Society of Bengal because “Coleridge's earliest work as a writer was included or reviewed in periodicals which were paying tribute to and disseminating the work of Jones and his 'disciples"' (Drew 192). ${ }^{49}$ Coleridge's connection to the works of Jones is significant, for they give scholars an idea as to what Coleridge's initial knowledge of Buddhism might have been.

On the basis of the manner in which Sir William Jones represented Buddhism, it is safe to assume that Coleridge's overall understanding of Buddhism is intertwined with his knowledge of Hinduism, for Sir William Jones erroneously mistook Buddhism and Jainism as sects of Hinduism rather than separate religions. According to Kurt A. Johnson in "William Jones and Representations of Hinduism in British Poetry," "Jones writes how 'the works of the...Bauddhas...[and] Jainas' are 'heterodox' philosophies diverging from what he considers to be conventional Hinduism" (28). Further erasing the line of demarcation between Buddhism and Hinduism, Jones also describes the Buddha

\footnotetext{
${ }^{49}$ For the names of magazines and periodicals that printed the works of both authors (i.e., Jones and Coleridge), see Chapter 6 of Drew's India and the Romantic Imagination.
} 
as being "dissented" from "orthodox Bráhmens" (q0 (q. in Johnson 28). As a consequence of Jones' Hindu-centered interpretation of Buddhism, the Buddha is depicted as the reincarnated "Vishnu called Sugata-Buddha" (Johnson 28). Although Buddhism and Hinduism do share many similarities, for the young Siddhartha ${ }^{51}$ himself was a Hindu, and Buddhism does take certain ideas from Hinduism (and vice versa), the Buddha later in life rejected many aspects of Hinduism. ${ }^{52}$ In denying any separate identity between Hinduism and Buddhism, Jones offers his readers a less than accurate representation of these religions.

Because of the manner in which the Buddha figure is represented in Jones' works, it is possible that Coleridge may have been referring to Jones' Sugata-Buddha when he compared himself to Vishnu. In his Oct. 14, 1797 letter to Thelwall, which was written only a few months after "Kubla Khan," Coleridge writes:

I should much wish like the Indian Vishna to float about along an infinite ocean cradled in the flower of the Lotos, \& wake once in a million years for a few minutes - just to know that I was going to sleep a million more years. (qtd. in Beer 99) ${ }^{53}$

\footnotetext{
${ }^{50}$ The description of the Buddha provided by Sir William Jones is purely within the theology of Hinduism, for Hindus appointed the Buddha as the "ninth incarnation of the god Vishnu" (Maguire 42).

51 The Buddha's name, Siddhartha, is most often used when referring to the Buddha before he achieved enlightenment.

52 The major components of Hinduism rejected by the Buddha include: the teachings of the Vedas, animal sacrifice, the reliance on gods, and the authority of the Brahmins, or Vedic priests. See Chapter 1, "Historical Overview: The Context Out of Which Buddhism Emerged," of Jacob Kinnard's The Emergence of Buddhism.

${ }^{53}$ Coleridge follows his description with: "I have put this feeling in the mouth of Allhadra, my Moorish woman" in "Osorio" (Griggs 350).
} 
What is interesting about the above passage is that Coleridge seems to confuse Vishnu for Brahma, an error that highlights his less-than-perfect understanding of Hinduism.

According to Johnson, Vishnu does not sit upon a lotus, as described by Coleridge, but on a snake. Instead, it is Brahma who floats upon a lotus (Johnson 11). Like Brahma, the Buddha is also represented as sitting on a lotus. According to Drew in India and the Romantic Imagination, "Such is the henotheistic atmosphere of Indian religion that the Buddhists also appropriated to [...] Buddha attributes of both Brahma and Vishnu" (192). Because all of these religious figures are displayed in conjunction with the lotus, and since the Buddha is also portrayed as an avatar for both Brahma and Vishnu, it is highly possible that Coleridge may have had the Buddha in mind when he likened himself to Vishnu. It is likely that Jones' works, which themselves display Jones' lack of understanding regarding Hinduism and Buddhism, may have been the catalyst for Coleridge's own confusion. ${ }^{54}$ Despite Coleridge's mistake, the above passage seems to indicate that Coleridge found within Eastern religions a figure he could relate to.

In addition to providing some perspective on Theravada Buddhism, Jones' works would have also exposed Coleridge to the different forms of Buddhism practiced throughout parts of Asia, such as Vajrayana Buddhism. Coleridge's notebook indicates that he took an interest in learning about Buddhist figures from the school of Vajrayana.

\footnotetext{
${ }^{54}$ Although some scholars argue that Coleridge was unable to fully separate Hinduism from Buddhism, Martin Jarrett-Kerr posits that Coleridge preferred Buddhism to Hinduism: "Coleridge threw out hints which suggest that he might have had more sympathy with Buddhism - if that is what he means by 'Their [the Hindus'] next neighbor of the North, the temple-throned infant of Thibet, with the Himala behind and the cradle of the Ganges at his feet'" (95). Despite Kerr's claim, Coleridge's statement is not clear in terms of exposing a preference for Buddhism. Additionally, Kerr's claim is lacking an explanation as to why the above passage displays a preference.
} 
For example, Coleridge responded to Jones' "On the Tartars" by writing in his notebook: "Kublai Khan ordered letters to be invented for his people-" (Drew 196). Although it is not known exactly why Coleridge felt compelled to write down such a specific fact about Kublai Khan, the above comment does highlight Coleridge's knowledge on an important Buddhist figure.

Although Jones and Wilkins seem to have had the greatest impact on Coleridge in terms of "textual encounters" (Lussier, "Buddhism and Romanticism" 1107) with Buddhism, the works of Samuel Purchas and Marco Polo may have also played an important role in shaping Coleridge's understanding of the religion - particularly in terms of Mahayana and Vajrayana Buddhism. According to Drew, from reading Purchas's Pilgrimage,${ }^{55}$ Coleridge's "mind would have been left with a reasonably accurate impression of the Tartar court" (194). We know that Purchas's Pilgrimage had a substantial effect on Coleridge, for he himself admitted that it spurred the dream that inspired "Kubla Khan" (Abrams). Marco Polo's works would have also further expanded Coleridge's knowledge of “Kublai's world” (Drew 194). According to Rossabi in Khubilai Khan: His Life and Times, "Marco asserts that he and Khubilai had numerous conversations, ${ }^{56}$ and he offers a vivid, colorful verbal portrait of the Great Khan. He saw Khubilai at the height of his powers and describes the Great Khan in a flattering light" (151). In addition to providing Coleridge with a full understanding of the Mongols,

\footnotetext{
${ }^{55}$ Volumes one and three would have had the greatest impact in terms of exposure to Buddhism, for volume one explores the "African coast to the East Indies, China, and Japan," whereas volume three focuses on "Tartary, Russia, and China" (Rawlinson xiii).

${ }^{56}$ Several of the conversations that took place between Marco Polo and Kublai Khan dealt with the subject of Buddhism (Rossabi 39).
} 
Kublai Khan, and the Tartar court, Marco Polo's works would have also illuminated for Coleridge "the seminal story of Buddha's life" $" 57$ as well as "the theology of the Buddhists" (Drew 194-195).

In addition to Purchas and Polo, Coffman documents Coleridge as having read a significant number of texts that may have exposed him to Buddhism. ${ }^{58}$ Some of these important texts are: The Annual Register, vol. XXIV (1782), ${ }^{59}$ twelve works by William Lisle Bowles (1796-1816), ${ }^{60}$ John Crawfurd's History of Indian Archipelago: Containing an account of the manners, arts, languages, religions, institutions, and commerce of its inhabitants (1820), ${ }^{61}$ The Critical Review; or Annals of literature (1756-1817), ${ }^{62}$ Jean

57 "Of the Buddha [Marco Polo] wrote: 'But it is certain, had he been baptized a Christian, he would have been a great saint alongside our Lord Jesus Christ"” (qtd. in Keown 117).

${ }^{58}$ Many of these consist of travel narratives. According to Coffman, "Coleridge's spirit was restless in June 1793 as he began to pursue the literature of travel and geography" $(\mathrm{XV})$.

${ }^{59}$ Coleridge checked out volume XXIV of The Annual Register from the Bristol Library from Feb. 26 - March 10, 1796. Volume XXIV contains "a reference to Halhed's Code of Gentoo Laws" (Drew 191). Drew credits Halhed for Coleridge's knowledge on "Brahmin belief" (Drew 191).

${ }^{60}$ In "Coleridge, Vishnu, and the Infinite," Aparajita Mazumder identifies Bowles as one of the Romantic writers who felt "the allure of India" (32). In Coleridge: Early Visions, Holmes discusses the literary impact Bowles had on Coleridge. Coleridge's enthrallment with Bowles is made evident by juxtaposing Bowles' The Spirit of Discovery; or, the Conquest of the Ocean with The Rime of the Ancient Mariner, for there are similarities between the two poems.

${ }^{61}$ Coleridge responds to History of Indian Archipelago in On the Constitution of the Church and State (Colmer 89).

${ }^{62}$ Coleridge would have had access to all 144 volumes of The Critical Review located in the Bristol Library (Coffman 57). Holmes documents Coleridge as having regularly read The Critical Review because the magazine often published Coleridge's poems, as well as 
Antoine Dubois' Description of the character, manners and customs of the people of India; and their institutions, religions and civil (1817), ${ }^{63}$ Reverend William Enfield's The History of Philosophy, vol. 1-2 (1791), ${ }^{64}$ and Abraham Parson's Travels in Asia and Africa (1808). ${ }^{65}$ Mazumder adds to the list in "Coleridge, Vishnu, and the Infinite" by including Maurice's History of Hindostan (1795). ${ }^{66}$ Those texts published before The Rime of the Ancient Mariner are likely to have had an influence on the first composition of the poem. The texts published after the first composition of The Rime of the Ancient Mariner may have had an effect on the many revised editions of the poem, for Coleridge continued to revise the poem until $1828 .{ }^{67}$

reviews for those poems. Coleridge was highly offended by the reviews Southey wrote in The Critical Review, which criticized The Rime of the Ancient Mariner, "The Idiot Boy," and "The Thorn" (Holmes 200).

${ }^{63}$ Coleridge responds to Dubois' text by writing in the margins of the book. For Coleridge's response, see Natale's The One Life and Drew's India and the Romantic Imagination.

${ }^{64}$ The History of Philosophy would have exposed Coleridge to three important figures believed to have traveled to India: Pythagoras, Apollonius of Tyana, and Alexander the Great (Drew). Drew documents Coleridge as having "read both volumes" (186) from the Bristol Library "before taking out Brucker's German original” (186).

${ }^{65}$ Coleridge read Robert Southey's copy of Parson's text "while he was staying at Greta Hall" (Mays 902). Coleridge responds to a gloss regarding Bombay by writing on Southey's copy. For Coleridge's response, see Vol. 16 of J.C.C. Mays' The Collected Works of Samuel Taylor Coleridge.

${ }^{66}$ Mazumder, Drew, and Lowes argue that Coleridge not only read Maurice's History of Hindostan, he also took from it the image of Vishnu reposing, which he likened himself to in his 1797 letter to Thelwall. Coleridge also mentions Maurice's text in one of his notebooks. For Coleridge's comment on History of Hindostan, see John Livingston Lowes' The Road to Xanadu.

${ }^{67}$ The 1828 version appears "in Coleridge's collected edition of 1834 , the year of his death" (Fry 12). 
As a consequence of the extensive reading Coleridge had conducted on the subject of India, it is not surprising that Coleridge knew enough about Buddhism to correct Dubois' commentary on the similarity between Buddhism and materialism. In Description of the character, manners and customs of the people of India; and their institutions, religions and civil, Dubois states:

There is still another scheme of philosophy, which is utterly rejected by the Brahmans, and is said to be followed and taught by the Jainas and the votaries of Buddha. This system is nothing else than the pure "Materialism", which Spinoza and his disciples have endeavored to pass for a new discovery of their own. (qtd. in Natale 357)

Dubois' "materialism" is the ontological viewpoint that "everything that actually exists is material, or physical" (Moser and Trout 1). In other words, "everything that exists is extended in [physical] space, that nothing non-spatial exists" (Moser and Trout 1). In his notes, Coleridge counters Dubois' comparison: "Nonsense! [...] these Buddhists are not Materialists" (qtd. in Natale 357). Coleridge's counterargument is correct, for in the Mahayana text of the Lankavatara Sutra, the Buddha is portrayed as having spoken against materialism:

[...] there is that which does not belong to materialism and which is not reached by your wisdom nor by that of the philosophers who cling to false discriminations and wrong reasonings as they fail to see the unreality of external objects. By this is meant the cessation of discrimination. When it is recognized that there is nothing beyond what is seen of the mind itself, the discrimination of being and non-being ceases; as thus there is now no external world as the object of perception, discrimination abides in its own abode. This is not of materialism. (Suzuki 154)

While it is unlikely that Coleridge had access to the Lankavatara Sutra, his rejection of the Buddhism-Materialism comparison made by Dubious seems to indicate that Coleridge possessed some knowledge of the core teachings of Buddhism. 
Although Coleridge's reading choices display his unbridled enthrallment with Eastern cultures, philosophies, and religions, it is important to acknowledge that in his later years Coleridge displayed a drastic shift in his perception and reception of nonChristian texts. Instead of approaching Eastern manuscripts with "awe" (qtd. in Drew185), Coleridge began to skeptically ask, "What are These Potentates of inmost Ind [sic]?" (qtd. in Drew 185). According to Muirhead in Coleridge as Philosopher, "Upon reflection, [Coleridge] thought that the rarity and difficulty of their achievement had erroneously if understandably led Jones and Wilkins - and thereby himself - to treat as awesome Indian works thought to be so ancient they were regarded as antiquity itself" (qtd. in Drew 185). Coleridge's change in sentiment is most prominent in lecture III of Coleridge's Philosophical Lectures ${ }^{68}$ where he seems to have purposely chosen a specific passage from the Bhagavad-Gita in order to arouse fear and horror within the hearts of his listeners. The Vishnu described by Coleridge in these lectures, juxtaposed with the sleepy, peaceful Vishnu he likened himself to in 1797, is portrayed as a monstrous, fearful being "with many mouths and eyes; with many arms, ${ }^{69}$ and legs, and breasts; with many bellies and with rows of dreadful teeth!" (qtd. in Mazumder 46). Unlike Coleridge's life-giving Vishnu of 1797, the Vishnu of his Philosophical Lectures is symbolic of death and destruction:

[...] even the fronts of our army, seem to be precipitating themselves hastily into thy mouths, discovering thy teeth with their bodies sorely mangled. As the rapid streams of full flowing rivers roll on to meet the

\footnotetext{
${ }^{68}$ Conducted between Dec. 14, 1818 and March 29, 1819 (Mazumder).

${ }^{69}$ Several Buddha deities are portrayed with multiple limbs and faces. For example, Bodhisattva Avalokitesvara is often illustrated with "a thousand arms and faces, indicating that his compassion is universal and inexhaustible" (Keown 68).
} 
ocean's bed, even so these heroes of the human race rush on towards thy flaming mouths. As troops of insects, with increasing speed, seek their own destruction in the flaming fire [...]. Thou involvest and swallowest them altogether, even unto the last, with thy flaming mouths. (qtd. in Mazumder 46)

Coleridge rhetorically chose the above passage from the Bhagavad-Gita in order "to illustrate to his English audience how in the name of pantheism mankind might sink into 'the worst escapes and the blindest superstition"” (qtd. in Mazumder 46-47).

As explained by Mellor in English Romantic Irony, the impetus for Coleridge's shift in perception can be attributed to several factors. For starters, Coleridge was poignantly aware of the importance of gaining the interest of patrons who could provide him and his family with financial security. Consequently, Coleridge had to produce work that would arouse and maintain the public's interest. Since Coleridge catered to a largely Christian audience, it would thus make sense that his efforts would be geared toward producing work that spoke to those unique values, and Coleridge's Philosophical Lectures are a good example of that. In addition to the necessity of captivating wealthy patrons, Coleridge was also quite sensitive to the criticisms of others, which is one reason why Coleridge revised The Rime of the Ancient Mariner several times throughout the course of his lifetime. The supernatural elements of the poem, contrasted with Wordsworth's “secularized Christianity" (Mellor 142) - or to borrow from Mellor, the romantic irony ${ }^{70}$ present within the poem - were the reasons for many of the harsh reviews Lyrical Ballads received (Mellor). Mellor postulates that these critiques, which

\footnotetext{
${ }^{70}$ Using The Rime of the Ancient Mariner, Mellor describes "Romantic irony" as the intermingling of two metaphysically contradictory ideas, such as an unconscious "Free Life" with that of an ordered "Confining Form" (137). According to Mellor, several of Coleridge's poems oscillate between chaos (non-Christian) and logic/order (Christian).
} 
Coleridge did not receive well, were the impetus for the dogmatic Christian views he later embraced, as well as his rejection of all non-Christian viewpoints, particularly those he had been so fond of previously, such as those of Eastern religions. Because of Coleridge's growing intolerance for non-Christian theology, the 1828 edition of the poem was not chosen for analysis even though Coleridge continued to learn about Eastern philosophies and religions up until his death.

Another reason for the dramatic transformation Coleridge undergoes in his reception of non-Christian texts and perspectives dwells within the realm of guilt, which was caused by "his secret religious doubts" (Holmes 49). Mellor speculates that Coleridge "desperately wanted to believe in the absolute validity of an ordered Christian universe but could not, could not because of his own acute intelligence perceived the existence of an underlying chaos" (137). The many revisions Coleridge made to The Rime of the Ancient Mariner chronicles his oscillation between wanting to explore chaos (Eastern viewpoints) and wanting to alleviate the fear brought upon by that chaos by providing himself and his audience with an ordered, Western viewpoint that showcases a God who rights the wrongs of the world (Mellor). Not being able to reconcile the distinction between order/confining form and chaos/free life brought Coleridge a great deal of internal anguish and guilt (Mellor). It is possible that Coleridge found it easier to simply reject ideas that opposed what he desired to perceive as true rather than to continue to torment himself with philosophies that threatened to eradiate his core beliefs. ${ }^{71}$ According to Paul Fry in "Biological and Historical Contexts," the different

\footnotetext{
${ }^{71}$ On a side note: A Buddhist interpretation of the argument Mellor establishes would liken the seemingly dualistic concepts of samsara (the cycle of death and rebirth) and
} 
perspectives in the poem have encouraged many scholars to identify the poem as a series of fragments, rather than an organic whole. Following Fry's postulation that the poem is fragmented, and following Mellor's claim that the poem oscillates between Christian and non-Christian viewpoints, this thesis solely analyzes those moments (or fragments) in the poem that lend themselves to a Buddhist framework.

Despite the ambivalence Coleridge exudes regarding Eastern religions, what is important here is that a movement took place - a movement from being in favor of exploring non-Christian viewpoints to being rigid in his rejection of anything that opposes Christian theology. Such a movement suggests that Coleridge not only looked upon Eastern religions with admiration at some point in his life, but also that he studied these religions - as displayed by his extensive collection of books on the subject. The shift he later undergoes, which occurs long after writing The Rime of the Ancient Mariner, does not negate the importance of including Coleridge within Buddhist Romantic Studies, especially when research shows that he was versed in Buddhist theology. Despite Coleridge's cognizance of Buddhism, it is not the aim of this study to prove that Coleridge purposely imbued The Rime of the Ancient Mariner with Buddhist concepts. It is solely to show that those elements of Buddhism are in fact there in order to open up a space for The Rime of the Ancient Mariner within academic discourses. The following chapter attempts to create such a space.

nirvana (freedom from the cycle of death and rebirth) with Mellor's concepts of "confining form" (137) and "free life" (137). Symbolic of order, samsara is confining form, and nirvana - symbolic of the annihilation of all forms - is free life. Buddhist philosophy moves beyond dualism by teaching that samsara and nirvana are actually one and the same, for one cannot exist without the other. Interestingly enough, the chaos and order within The Rime of the Ancient Mariner - as described by Mellor - work within the same vein; Coleridge's chaos cannot exist without order. 


\section{THE MARINER'S SUTRA ON PRAJNA - A BUDDHIST APPROACH TO THE MARINER'S COGNITIVE JOURNEY FROM IGNORANCE TO ENLIGHTENMENT}

"That all might know the Truth, and that the Truth might make us Free."72

-The Watchman

In accordance with Buddhist philosophy, Coleridge's philosophical musings often landed on the subject of wisdom and the necessity of cultivating the mind through arduous discipline, true reflection, and conscientious meditation. Chapter 5 of Biographia Literaria highlights Coleridge's unique interest in using awareness and meditation as a means for developing genuine wisdom: "First studied patiently, meditated deeply, understood minutely, till knowledge, become habitual and intuitive" (qtd. in Shawcross 19). Although Coleridge's poetry, prose, letters, and journals all expose his interest on the subject of wisdom, the unique role wisdom plays within The Rime of the Ancient Mariner differs from Coleridge's other works; for instance, the didactic message guiding The Rime of the Ancient Mariner points at a correlation between suffering and lack of wisdom. Such an approach to the concept of wisdom connects Coleridge to Buddhist philosophy, which teaches that dukkha ${ }^{73}$ is a direct result of ignorance. Parallel to Buddhism, the poem also highlights meditation as a means for transcending dukkha through the cultivation of compassionate prajna. Prajna plays an integral role in

\footnotetext{
${ }^{72}$ According to Holmes in Coleridge: Early Visions, Coleridge was so fond of the passage from St. John's Gospel that he chose it as The Watchman's motto (107). The motto captures the essence of Buddhism, for Buddhists believe that by awakening to truth, humans are able to free themselves from the cycle of suffering.

${ }^{73}$ As discussed in Chapter 1, dukkha can be difficult to translate into English. However, Rahula identifies dukkha as playing an important role in Buddhism for its association with the First Noble Truth taught by the Buddha. The First Noble Truth teaches that unawakened life is dukkha.
} 
Buddhism, and it is described as "insight into the nature of reality of the kind which comes through long reflection and deep thought $[\ldots]$ which deepens over time and eventually reaches full maturity in the complete awakening experienced by the Buddha" (Keown 47). Interestingly, the Mariner's own story mimics the process associated with prajna. In order to analyze the role prajna plays within The Rime of the Ancient Mariner, this chapter examines the cognitive transformation exhibited by the Mariner, who begins his own story as an ignorant, suffering being who misperceives himself as separate and superior to nature. Despite his initial lack of prajna, through the transcending process of meditation, the Mariner evolves into an all-seeing, compassionate Buddha who selflessly delays nirvana for the sake of spreading enlightenment.

In order to trace the Mariner's journey from ignorance to enlightenment, it is necessary to begin with the story the Mariner tells, for it is here where readers are clued into the Mariner's lack of prajna, which is conveyed through his dualistically absurd view of the natural environment. That the Mariner possesses such a perception is evident when he describes the wind as an aggressive "foe" (47) who violently assaults the ship: "And now the STORM-BLAST came, and he / Was tyrannous strong: / He struck with his o'ertaking wings / And chased us south along" (41-44). Although the wind provides the ship with much-needed movement, the shipmates are described as victims attempting to flee the wind. The Mariner's juxtaposition between the docile, innocent crew and the aggressive, malevolent wind constructs a dichotomy between humans and the natural environment. In the binary relationship between humans and nature, the natural environment is perceived as the frightful 'other' - an entity that is separate from and unrelated to the mariners. The Mariner's discursive mode of thinking creates a space for 
him to demonize the wind as hostile while simultaneously elevating humans to a status above the unreasonable barbarism of nature. The illogicality of such an ideology is heightened by the Mariner's role as a seafaring man, for a mariner cannot work without wind; in fact, the wind should be perceived as a mariner's greatest ally. Because the mariners require wind, the underlying message here (which undermines the Mariner's point of view) points at an interrelated relationship between man and environment; without prajna, the Mariner fails to grasp the unifying, collective truth.

Unveiling the faulty logic behind a differentiation between self (humans) and other (nature), the Mariner's discriminatory perception of the natural environment leads to feelings of dukkha. The dejection experienced by the Mariner helps to cement him as an unenlightened being, for dukkha is a condition of the unawakened mind. The correlation between unawakened, discriminatory perception and suffering is exposed when the Mariner presents his outlook on the surrounding area:

And through the drifts the snowy cliffs

Did send a dismal sheen:

Nor shapes of men nor beasts we ken The ice was all between.

The ice was here, the ice was there, The ice was all around; It cracked and growled, and roared and howled, Like noises in a swound! (55-62)

In the passage above, the language used by the Mariner conveys a sense of wretchedness, and he blames the natural environment for the anguish he feels. Unlike the mariners, who quietly and passively observe nature, the natural environment is portrayed as having a heightened level of autonomy, and it uses its sovereignty to inflict misery onto the mariners. For example, it is the snowy cliffs that cast darkness and gloom onto the world 
with its overrun, sun-blocked structure; and it is the ice that quarantines the mariners from civilization through insistent growls, roars, and howls. Despite the morose feelings that arise in portraying nature as sovereign and malevolent, the Mariner is able to establish an identity for himself through the juxtaposition of humans (self) and nature (other). More importantly, the Mariner's binary construction exposes his own desire to play the role of sufferer; every victim needs a victimizer, and the Mariner designates the natural environment with that position in order to ensure his own existence.

Aside from his identification as a victim, the desire for an identity itself creates further suffering. The Second Noble Truth supports the correlation between desires and despondency by emphasizing tanha as the catalyst for dukkha. ${ }^{74}$ In What the Buddha Taught, Rahula defines tanha as "thirst, desire, greed, craving, manifesting itself in various ways, that gives rise to all forms of suffering and the continuity of beings" (29). Tanha is described as manifesting itself in three ways: 1) craving "gratification through the objects of the senses;" 2) craving for "existence;" and 3) craving to "destroy" (Keown 52). In accordance with the second manifestation of tanha, the Mariner's thirst for an identity is in reality a desire to secure and aggrandize his own existence. However, the thirst for existence will always result in dukkha because all things are impermanent (anicca); even the self must one day cease to be. Additionally, the unique and separate 'I' that arises out of a desire to exist is dependent on an equally impermanent external world for its identity.

\footnotetext{
${ }^{74}$ According to the Dalai Lama, not all desires are harmful. However, all ego-based desires are harmful to the self and others (Grubin). To distinguish positive desires from negative desires (tanha), positive desires are referred to as chanda (Keown 53).
} 
If the impermanent external changes - as it usually does, the result is dukkha, for the dependent 'I' then ceases to exist without the 'other.' For example, at the very beginning of the Mariner's story, when the ship has just left the shore, he describes his experience positively: "The ship was cheered, the harbor cleared, / Merrily did we drop" (21-22). Although the Mariner does not describe the external environment in depth as he does later in his story, the overall sense conveyed at the very beginning of the Mariner's journey is one of joy and excitement - a contrast from his morose demeanor a few lines later. However, the weather eventually turns "wondrous cold," (52) and the natural environment changes its external appearance with strong winds, snow, and cliffs. The Mariner is then forced to redefine who he is in juxtaposition to the new 'other' in order to quench his thirst for existence, which is why he reinvents himself as a victim. According to Buddhist philosophy, the desire for an 'I' is what brings about suffering. To end suffering, the 'I' (atman) must be transcended, resulting in no-self (anatta), for if no-self exists, then there is no one to experience unrelenting tanha or dukkha (Maguire).

Because the separate 'I' and 'other' function as illusory concepts, instead of attributing any inherent quality to nature - as the Mariner does, a Buddhist interpretation of the unsatisfactoriness the Mariner feels would point at the Mariner's own mind rather than the external world. Referring back to the Zen koan from the Platform Sutra - "Not the Wind, Not the Flag, ${ }^{95}$ - mentioned in Chapter 2, readers can see the great emphasis

${ }^{75}$ The koan reads: "At a certain time a flag was blowing about in the wind. One monk said, 'The wind is moving'; another said, 'The flag is moving,' and quarreling was endless. Enô (the $6^{\text {th }}$ patriarch) said, 'The wind is not moving, the flag is not moving; what is moving is your minds"" (qtd. in Blyth 161). 
that is placed on the mind, for it is the mind that moves rather than the flag or the wind. ${ }^{76}$ "This koan demonstrates the realization that in naming an object one may cloud one's understanding of the true nature of mind by falling into externalization and believing that the true nature of the flag, the wind, and the mind are different" (New World Encyclopedia). "Not the Wind, Not the Flag" is pertinent for understanding the suffering the Mariner experiences because that suffering has its basis in dualistic thinking.

Contrary to the Mariner's dualistic perception of the natural environment, Buddhism stresses the interrelatedness, interconnectedness, and oneness of all things. In the Zen sect of Buddhism, the idea of oneness is further emphasized by the belief that all things - even inanimate objects - possess Buddha-nature. ${ }^{77}$ As explained by Dogen, Buddha-nature is not a state one must attain, but rather, all things are naturally Buddhanature (qtd. in Masao). Within the Zen framework, the wind, cliffs, and ice are Buddhanature, and consequently, none of the alarming characteristics the Mariner imbues them with are characteristics they truly possesses. In discerning a self, the Mariner fails to see that the mind, cliffs, ice, and wind are all one - just as the flag, wind, and mind are one in the koan above.

Despite the inherent oneness of all things, the Mariner's delusional mental state does not allow him to perceive oneness. In the Dhammapada, ${ }^{78}$ the Buddha is said to

\footnotetext{
${ }^{76}$ Nun Miaoxin took the concept of non-duality further by stating: "It's neither the wind, nor the flag, nor the mind that is moving" (Loori 198). Loori comments on "Not the Wind, Not the Flag" in The True Dharma Eye with the "Capping Verse": "Wind, flag, mind - / bah, humbug! / If you wish to attain intimacy / just close the gap" (198).

${ }^{77}$ The concept of Buddha-nature is explained in more detail in Chapter 1.

${ }^{78}$ The Dhammapada consists of the Buddha's axioms from the Pali canon (Maguire).
} 
have discussed the transformative power of the mind by attributing it the ability to shape both our realities and ourselves: "All that we are is the result of what we have thought: it is founded on our thoughts, it is made up of our own thoughts" (Muller 2). If a mind is unawakened, the realities of that mind will be shaped by ignorance, and thus, whatever that mind perceives will be illusory - a mere construction of the ignorant, tanha-centered mind. Following the philosophy of the Dhammapada, the monstrous qualities the Mariner projects upon nature are in reality the characteristics of the Mariner's own tormented, unenlightened mind. ${ }^{79}$ In blaming his sense of despondency on nature, the Mariner fails to understand the unique role his mind plays in shaping his reality. ${ }^{80}$

Focusing on the conscious, awakened mind as the vehicle for happiness (contrary to the unawakened mind that yields dissatisfaction), a Buddhist approach to The Rime of the Ancient Mariner would focus on the Mariner's dejection as an indication of the Mariner's lack of prajna. In opposition to the mopey character of the Mariner, enlightened beings are often portrayed with smiles on their faces within Buddhist literature and paintings. Most Westerners would recognize the correlation between enlightenment and happiness through the image of Budai, or the Laughing Buddha ${ }^{81}-\mathrm{a}$

\footnotetext{
${ }^{79}$ As discussed in Chapter 1, Blyth makes a similar assertion in Zen in English Literature and Oriental Classics. However, he attributes the silence found in nature to the tranquility of the Mariner's mind, which is projected outward.

${ }^{80}$ Coleridge conveys a similar idea in "The Nightingale," where the speaker imbues nature with his own sadness: "A melancholy bird! Oh! idle thought! / In nature there is nothing melancholy. / But some night-wandering man whose heart was pierced [...] / First named those notes a melancholy strain" (14-22).

${ }^{81}$ Although not to be confused with Siddhartha Gautama, some sects of Buddhism perceive Budai as a bodhisattva or Buddha figure.
} 
Chinese Buddhist figure who is often depicted with a colossal smile and a jolly belly.

Within the context of Zen, a smile can also be perceived as a sign of instant enlightenment:

The Buddha is said to have given a 'silent sermon' once during which he held a flower and gazed at it. After a while, one of those present, a monk called Mahakasyapa, began to smile [...]. According to legend, that smile (that is to say, realization) was handed down by twenty-eight successive masters and much later became the origin of Zen. (Tolle 2)

Buddhist philosophy posits that the source of happiness for these enlightened beings comes from a heightened state of consciousness that is free from the "me and mine" (Keown 55) of the ego. Enlightened beings, or buddhas, are able to perceive things as they truly are because they are not confined by the ego's insistent judgment and biases. The shedding of ignorance and the awakening to nirvana, or reality, results in the ultimate end of suffering and dissatisfaction, which creates a space for contentment. Lacking in satisfaction and joy, and submerged in dukkha, the Mariner is the epitome of ignorance.

Contrary to the happy, enlightened Buddha deities who have transcended the ego, the Mariner's unrelenting desire to aggrandize the self is what leads him to commit the ultimate act of ignorance and delusion by killing the albatross. Because the egotistical tanha can never be satisfied, ${ }^{82}$ the illusory 'I' that comes from the desire to exist must always look for ways to validate its own existence - lest it be annihilated. The impossibility of satiating the tanha to exist is seen when the Mariner once again reinvents

\footnotetext{
${ }^{82}$ The insatiableness of tanha in Buddhism is emphasized through hungry ghosts. "For the most part, ghosts are former human beings who developed strong attachments which keep them bound to the earth. They are consumed by desires they can never satisfy, and depicted in popular art as wraith-like creatures with large stomachs and tiny mouths symbolizing their insatiable yet constantly unsatisfied hunger" (Keown 35).
} 
the external environment in order to solidify his own self. Diverging from the gloomy manner in which the Mariner perceived nature (i.e., wind, snow, and cliffs), when the albatross appears, the Mariner again shifts his perception of the environment from hostile to pleasant. The change in perception is noticed when the Mariner refers to the previously "tyrannous" (42) breeze as "the good south wind" (71). As mentioned by the Buddha in the Dhammapada, perception is dependent on thoughts, and so the change the Mariner discerns in nature is symbolic of a shift in the Mariner's own mind - rather than a change in the external environment. Because there is a shift in the Mariner's mind, the Mariner is once again forced to reinvent the 'other' in order to satiate the tanha for a unique and independent 'I.' The Mariner succeeds in reinventing the other by inversing the hierarchy he had previously constructed. Instead of playing the part of a victim, with nature playing the role of aggressor, the Mariner becomes the aggressor by killing the albatross, and nature is subjected to the role of victim.

Although no light is shed upon the Mariner's motive for killing the albatross, he does keep the bird's corpse, which suggests that his purpose for killing the alabtross is the result of a thirst to reinvent and aggrandize the self. That the Mariner keeps the bird's corpse is insinuated when the albatross is placed, several days later, upon the Mariner's neck as punishment: “[...] the Albatross / About my neck was hung” (141-142). It is difficult to surmise why the albatross' corpse is kept on board "day after day, day after day" (115), especially when the weather is described as "hot" (111). If the Mariner had shot it down for food or fur, the shipmates would have prepared the meat or fur soon after the killing in order to beat the process of decay. On the other hand, if the albatross served no practical purpose for the shipmates, the corpse would have been thrown overboard to 
avoid the spread of bacteria and disease. Despite the plethora of reasons for why an animal's corpse should not remain on the deck of a "hot" (111) ship for several days, the corpse oddly remains on deck amidst the mariners. Because there are no practical reasons for keeping the corpse, the albatross can be interpreted as being some sort of trophy for the Mariner. The albatross, as a trophy, serves to highlight the Mariner's thirst for selfaggrandizement. Juxtaposed with the beginning of the poem, where the Mariner appears fearful of, or belittled by, the natural environment, the moment where the Mariner kills the albatross is an ultimate display of power and dominance over the 'other.' As a trophy, the albatross' corpse validates the powerful and dominant 'I.'

Interestingly, the egotistical outlook the Mariner develops regarding the natural environment is parallel to Christian ideology, which teaches that animals were created for human use and consumption. In Genesis, God is portrayed as saying to Noah:

And the fear of you and the dread of you shall be upon every beast of the earth, and upon every fowl of the air, upon all that moveth upon the earth, and upon all the fishes of the sea; into your hand are they delivered. Every moving thing that liveth shall be meat for you; even as the green herb have I given you all things. (King James Version, Gen. 9.2-3)

The theology expressed above relies on the differentiation of 'self' and 'other' in order to objectify animals to the will of humans, the subjects. The Mariner's acceptance of the above anthropocentric perception of the natural environment is exposed through the sense of entitlement the Mariner conveys in being able to kill an animal, for he offers no reason for his action; he simply and blatantly states: "With my cross-bow / I shot the ALBATROSS!” (81-82). Without compassion (karuna) for the albatross, a declared motive, or any apology, the Mariner appears to possess the popularly held Christian outlook, which posits that the natural environment is to be used as humans see fit (Bly). 
The values governing such an anthropocentric viewpoint would deem the Mariner's random act against nature as justifiable and ethical. ${ }^{83}$

However, the poem's gloss encourages readers to go against some aspects of Christian ideology by interpreting the killing of the albatross as a serious offense. ${ }^{84}$ Interestingly, the error lies in the Mariner's lack of compassion and friendliness toward the albatross: "The ancient Mariner inhospitably killeth the pious bird of good omen" (16). By using the word "inhospitably," the gloss insinuates that it is not enough for the Mariner to simply exist in the same space as the albatross; he must go beyond mere sideby-side existence and display charity and kindness. Because the albatross is displayed as having a natural right to benevolence (contrary to God's message to Noah), the message conveyed by the gloss points at a linear, rather than hierarchal, relationship between humans and environment.

With the law of ahimsa, Buddhism provides an understanding of the humannature relationship that coincides with the overall moral conveyed through the poem's

${ }^{83}$ Descartes popularized the objectification of animals by teaching that "animals were mere organic machines; if you whipped them, he said, there was no central consciousness in which the pain could be felt" (Perkins 3). Many of the Romantic poets both criticized and objected to Descartes' viewpoint in their works. For more information about the general perception of animals within the Romantic period, see the chapter titled "In the Beginning of Animal Rights" in David Perkins' Romanticism and Animal Rights and the chapter titled "The Attack on the Old Position" in Robert Bly's News of the Universe.

${ }^{84}$ Similar to the idea expressed by the gloss, one particular Buddhist story captures the wrongness of killing/harming birds. While hunting, Siddhartha's cousin (Devadatta) shot down a bird with an arrow (just as the Mariner had). Siddhartha finds and rescues the injured bird. Finding Siddhartha with the healed bird, Devadatta argues that the bird is his; Siddhartha disagrees. They decide to settle their dispute by consulting a sage. Favoring Siddhartha as the owner of the bird, the sage states: "If life has value, then surely the savior of that life owns it more than he who tried to kill it. For one sustains the life, while the other wastes it" (qtd. in Nelson). 
gloss. According to Keown in Buddhism, "At the heart of Buddhist ethics is the principle of non-harming (ahimsa) [...]. Buddhists have a scrupulous respect for all living creatures, whether human or animal, and regard the intentional destruction of life as a grave wrong" (Keown 11). Since the gloss stresses the idea of inhospitality, it is important to mention here that the law of ahimsa does not only cover physical violence it covers maltreatment in all its various forms. To be inhospitable is to withhold kindness and compassion; the absence of kindness and compassion creates a space for malevolence. The gloss bolsters such an idea by insinuating that it is cruel, and even unnatural, for humans to behave ungenerously toward animals; $;{ }^{85}$ such an assertion strips the Mariner of his self-given right to act upon others. By shedding his old perspective (self as victim), and adopting a Christian viewpoint surrounding animals and nature (self as dominant), the Mariner grows even more disconnected with reality. ${ }^{86}$

${ }^{85}$ The non-discriminatory postulation that humans should treat animals as hospitably as they would treat another human has been expressed by Coleridge, who often found himself "overflowing with talk and animal sympathies" (Holmes 151). Expressing his disgust at the thought of trapping and killing a mouse, Coleridge wrote in a letter to Cottle: "The mice play the very devil with us. It irks me to set a trap. By all the whiskers of all the pussies that have mewed plaintively, or amorously, since the days of Whittington, it is not fair [...]. 'Tis telling a lie. 'Tis as if you said, 'Here is a bit of toasted cheese; come little mice! I invite you!' - when, oh, foul breath of the rites of hospitality! I mean to assassinate my too credulous guests!" (Holmes 138-139). According to Holmes in Coleridge: Early Visions, "Coleridge, with his fraternal attitude toward animals, found himself in a ludicrous quandary, which curiously bears on the symbolism he would later apply to the shooting of the albatross. To kill them would be to betray them" (138).

${ }^{86}$ As discussed in Chapter 2, Coleridge possessed "secret religious doubts" (Holmes 49) regarding the Christian religion. The guilt Coleridge felt surrounding these doubts is evident throughout his works. For more on Coleridge's religious guilt, see Mellor's English Romantic Irony and Holmes' Coleridge: Early Visions. 
By killing the albatross, the Mariner exposes his severely disillusioned mindset, and the ignorance behind his action accounts for the fire imagery that appears soon after the albatross is killed. Displaying the harmful effects of ignorance-based thirst, Buddhists often describe persons overcome with ego-based desires as being on fire:

Craving fuels suffering in the way that wood fuels a fire: in a vivid metaphor in the Fire Sermon (S.iv.19) the Buddha spoke of all human experience as being 'ablaze' with desire. Fire is a good metaphor for desire since it consumes what it feeds on without being satisfied. It spreads rapidly, becomes attached to new objects, and burns with the pain of unassuaged longing. (Keown 51)

The fire imagery is also demonstrated in the concept of The Three Fires, ${ }^{87}$ which consists of ignorance, greed, and anger. In other words, it is ignorance, greed, and anger that make the consuming fire (Grubin); without ignorance, greed, and anger, there can be no consuming fire. In conjunction with the imagery of ignorance as fire, the word nirvana means "extinguishing" (Gach 77). In order to awaken to nirvana (i.e., reality), one must extinguish the fire of ignorance.

Although the image of fire is often used in Buddhism to represent tanha-based ignorance, it is important to mention that Nicherin Buddhism teaches that desires cannot be completed eliminated or extinguished. Instead, Nicherin Buddhism stresses the "transformation, rather than the elimination" of desires (Soka Gakkai International). Because desires can be transformed, the fire imagery in Nicherin Buddhism possesses more than one meaning. For example, consuming, tanha-based fire is representational of ignorance; however, the light of fire is symbolic of enlightenment: "burn the firewood of

${ }^{87}$ Also known as The Three Poisons (Gach 77). 
earthly desires and behold the fire of enlightened wisdom" (Soka Gakkai International).

Fire, as a representation of the light of enlightenment, is discussed later in this chapter.

The theme of fire as a representation for ignorance and greed ${ }^{88}$ is seen soon after the Mariner kills the albatross: "About, about, in reel and rout / The death-fires danced at night" $(127-128) .{ }^{89}$ Here, the fire is described as a consuming force that surrounds the ship. In the 1798 edition of the poem, Paul H. Fry in Case Studies in Contemporary Criticism provides a footnote to explain the sudden presence of fire: "St. Elmo's fire, an electrostatic glow on a ship's mast or rigging, thought to portend disaster" (36). However, the presence of St. Elmo's fire is not scientifically possible because there is no lightning or stormy weather present. According to Encyclopedia Britannica, St. Elmo's fire is defined as a

[...] luminosity accompanying brushlike discharges of atmospheric electricity that sometimes appears as a faint light on the extremities of pointed objects such as church towers or the masts of ships during stormy weather, or along electric power lines. It is commonly accompanied by a crackling or hissing noise. (para. 1)

Contrary to the atmospheric conditions required for St. Elmo's fire to occur, the weather at this juncture in the poem is characterized as being so hot and dry, it causes the shipmates to suffer from life-threatening thirst: "And every tongue, through utter drought,

\footnotetext{
${ }^{88}$ I have purposely left out anger, which is one of The Three Fires. Although the Mariner displays the characteristics of greed and ignorance throughout the poem, he does not, however, display anger.

${ }^{89}$ Another moment in the poem where the fire is described as a consuming force is when the Mariner spots the death ship. The Mariner describes the environment around him as being consumed by fire: "The western wave was all a-flame" (171). Significantly, in that exact moment in the poem, the Mariner encounters Life-in-Death, who is the epitome of tanha. Because of the role she plays in the poem, Life-in-Death can be interpreted as a hungry ghost.
} 
/ Was withered at the root" (135-136). Additionally, the environment is described as being eerily silent: "And we did speak only to break / The silence of the sea!" (105-106). The lack of lightning and stormy weather, as well as the lack of any hissing sounds, negates the possibility that the fire surrounding the ship could be St. Elmo's fire; instead, because it immediately follows the killing of the albatross, and because science is unable to explain its presence, the fire is symbolic of the Mariner's flaming thirst and greed.

Although the Mariner believes he sees fire, what is truly on fire is not the ship nor the horizon, but rather, it is the Mariner's own mind that is on fire with ignorance. In The Fire Sermon, the Buddha is shown as saying:

The mind is burning, ideas are burning, mind-consciousness is burning, mind-contact is burning, also whatever is felt as pleasant or painful or neither-painful-nor-pleasant that arises with mind-contact for its indispensable condition, that too is burning. Burning with what? Burning with the fire of lust, with the fire of hate, with the fire of delusion. I say it is burning with birth, aging and death, with sorrows, with lamentations, with pains, with griefs, with despairs. (Thera)

In depicting the Mariner's mind ablaze with ignorant desires, the didactic message driving the Mariner's tale points to the dangers of possessing such false viewpoints.

In addition to the consuming-fire imagery, the dangers of ignorance are exposed by the manner in which nature responds to the killing of the albatross. Following the Buddhist doctrine of Conditioned Genesis, the unnatural killing of the albatross immediately gives way to equally unnatural changes within the natural environment. Conditioned Genesis teaches that all things are interconnected, interrelated, and codependent:

When this is, that is [When A is, B is]; This arising, that arising [A arising, $\mathrm{B}$ arises]; When this is not, that is not [When A is not, B is not]; 
This ceasing, that ceases [A ceasing, B ceases]. (Rahula 53)

The interdependent concept of Conditioned Genesis is put into display with the wind, which had been forceful near the beginning of the Mariner's story, suddenly and mysteriously disappears after the albatross is killed. The kinship between the wind and albatross is suggested when the albatross first makes his appearance in line 63 of the poem, for as soon as he arrives, a southerly wind also appears from behind the ship: "And a good south wind sprung up behind" (71). Additionally, the gloss describes the albatross as moving in the same direction as the wind: "And lo! the albatross proveth a bird of good omen, and followeth the ship as it returned northward, through fog and floating ice" (15). Because they are interdependent, it is not surprising that the wind abruptly disappears once the albatross is killed: "Down dropt the breeze, the sails dropt down, / "Twas sad as sad could be" (107-108). Stressing the albatross-wind connection, the gloss reads, "The ship hath been suddenly becalmed" (20). Without the albatross, there is no wind (When A is not, B is not), and therefore, the ship stands "As idle as a painted ship / Upon a painted ocean" (117-118). Additionally, the blood shed by the albatross is also shed by the natural environment (When A is, B is), for the sun turned "bloody" (112) and the water "[...] burnt away / A still and awful red" (274-275). Like the decomposing corpse of the albatross, the sea is instantly filled with a slew of rotting creatures: "The very deep did rot: O Christ!" (123). Although insentient, the natural environment is portrayed as experiencing the same type of suffering sentient beings experience.

The "when this is not, that is not" law of Conditioned Genesis also provides insight into why the shipmates die soon after the albatross is killed. Although Life-in- 
Death initiates the mariners' deaths, the sound that ensues as their souls escape their bodies links them to the death of the albatross:

The souls did from their bodies fly, They fled to bliss or woe!

And every soul, it passed me by, Like the whiz of my CROSS-BOW! (224-227)

Whereas previously the death of the albatross was only mirrored within nature, when the mariners die as a result of the same event that caused the natural environment to react, their deaths work to eradicate the human-nature distinction created by the Mariner. The correlation between the death of the albatross and the death of the shipmates is significant to a Buddhist reading of The Rime of the Ancient Mariner, for it highlights the message that humans and animals are so interdependent that the absence of one leads to the absence of the other. ${ }^{90}$

The absence of any real distinction between humans and nature is embodied by the albatross himself, who is imbued with both animal and human qualities. For example, it is obvious that the albatross is anatomically a bird - an animal; however, the albatross is also personified: "The Albatross did follow, / And every day, for food or play, / Came to the Mariner's hollo!" (73-74). Described as taking part in "play" with humans, the albatross is likened to a child who takes pleasure in frolicking; the analogy made underlines the childlike innocence and good-naturedness of the "sweet bird" (88)qualities which are usually reserved for people rather than animals. More significantly, the lack of fear displayed by the albatross toward the humans exposes his prajna,

\footnotetext{
${ }^{90}$ Unlike the shipmates, the Mariner does not die as a result of the albatross' death. It appears as though the Mariner is singled out to undergo what he experiences, or rather, he is singled out to become a buddha, just as the Buddha was singled out - prior to his birth - to experience suffering in order to become a buddha.
} 
particularly when juxtaposed with the Mariner's fearful, discursive view of the external world near the beginning of the poem. Because when there is fear there is distinction and separation, the absence of fear displayed by the albatross hints at the albatross' knowledge regarding the oneness of all sentient and non-sentient beings. Bolstering the humanlike qualities of the bird, the albatross is also portrayed as being quite intelligent, for he is not only able to follow the ship, he can also discern when he - as opposed to someone else - is being called.

Anthropomorphized, the albatross resembles the manner in which the Buddha is portrayed in many of the stories within the Jataka Tales. "Resembling folktales in structure and moral content, [the Jataka Tales] collectively depict the Buddha's progression through various stages of being - plant, animal, and eventually human" (Maguire 8). Similar to the albatross, many of these future-Buddha animals are given human attributes and capabilities. ${ }^{91}$ Further connecting the Buddha with the albatross, several of these stories depict the Buddha's life as a bird, such as "Wise Birds and Foolish Birds," "Why the Owl is Not King of the Birds," "The Golden Mallard," and "The Crow." The didactic message behind the Jataka Tales stresses the interrelated concepts of reincarnation, enlightenment, and ahimsa. Like the Buddha, who once was a bird, the albatross possesses the ability to awaken to reality and become a Buddha, for the albatross is Buddha-nature itself - as explained previously by Dogen. Within the context

\footnotetext{
${ }^{91}$ The folktale dealing with the Banyan deer, who convinces the king to stop hunting, is a strong example of how animals are personified in the Jataka Tales (Maguire 8). See "The Banyan Deer" in Maguire's Essential Buddhism.
} 
of Buddha-nature, by murdering the albatross (or by killing any sentient being), the Mariner kills a buddha.

The identification of the albatross with the Buddha coincides with scholarly interpretations of the albatross as a Jesus figure. "In Mahayana Buddhist terms, Jesus [...] may be regarded as a bodhisattva" 92 (Wisdom Quarterly). A bodhisattva is "someone who takes a vow to work tirelessly over countless lives to lead others to nirvana [...]. It is compassion for the suffering of others which motivates a bodhisattva to sacrifice himself [or herself] on their behalf" (Keown 60-61). From a Buddhist perspective, the analogy between the historical Jesus and the bodhisattva is made because both figures are interpreted as compassionate teachers who sacrifice themselves for the wellbeing of others. For example, Jesus died for the sins of humanity, which then allowed the human race to be reconciled with God; the bodhisattva delays his or her own nirvana in order to help others end the cycle of death and rebirth. Many Buddhist teachers have made the Jesus-bodhisattva analogy, such as Thich Nhat Hanh and the Dalai Lama. The connections between Jesus and the bodhisattva figure "explains why some people regard Mahayana Buddhism as a form of messianic Asian Christianity” (Wisdom Quarterly). In addition to being a Buddha, the albatross can also be representative of a family member or friend through the concept of reincarnation. "According to Buddhism, in the long cycle of reincarnation we have all been each others' fathers, mothers, son, etc." (Keown 105). Within the framework of reincarnation, in not following the law of ahimsa,

92 "Bodhisattvas who reached the higher stages of their careers were visualized as enormously powerful beings, virtually identical to the Buddha [...]. The distinction between a Buddha and an advanced Bodhisattva becomes extremely blurred" (Keown $67)$. 
the Mariner kills more than a bird; with one single blow from his crossbow, the Mariner slays millions of people, and thus, millions of buddhas. The death and absence of millions of buddhas embodied in the albatross brings insight into why an entire ship of men suddenly die in response to the death of the albatross.

Despite the many clues that are given throughout The Rime of the Ancient Mariner to highlight the Mariner's lack of prajna, with the Mariner's transformation, the text also teaches that anyone can transcend ignorance and awaken to reality. Even though the degree of craving possessed by the Mariner is enough to cause immense chaos and suffering, the extremity of his ignorance does not dis-identify him with the Buddha figure because the idea that anyone can become a Buddha is at the core of the Buddha's teachings. Prior to his enlightenment,

[Prince] Siddhartha indulged in a life of pure pleasure, every whim satisfied, every desire fulfilled: 'I wore the most costly garments, ate the finest foods. I was surrounded by beautiful women. During the rainy season I stayed in my palace, where I was entertained by musicians and dancing girls. I never even thought of leaving.' (qtd. in Grubin)

After many years of a life of indulgence, and after several years of relentless seeking for ways in which to eliminate suffering, the Buddha eventually reached full enlightenment after meditating under a Bodhi tree.

Connecting the Mariner to the story of the historical Buddha, the Mariner also awakens to reality after a moment of intense meditation. That the Mariner achieves enlightenment so quickly is not surprising, for Buddhist texts are filled with people who suddenly and unexpectedly became enlightened after a moment of meditation. Meditation 
is defined as "an altered state of consciousness which is induced in a controlled manner" [...]. The goal of meditation is not to be 'elsewhere' but to be right here, fully conscious and aware" (Keown 91). In accordance with Keown's definition, the Mariner displays a level of intense mental concentration that can be compared to the 'now-ness' of meditation. Completely absorbed in the present, the Mariner watches the water snakes as they swim below him:

Beyond the shadow of the ship, I watched the water-snakes: They moved in tracks of shining white, And when they reared, the elfish light Fell off in hoary flakes.

Within the shadow of the ship I watched their rich attire: Blue, glossy green, and velvet black, They coiled and swam; and every track Was a flash of golden fire. (276-285)

As he gazes upon the water snakes, the Mariner falls into a form of meditation referred to as vipassana,${ }^{93}$ which "is aimed at seeing a particular phenomenon or concept with full clarity" (Maguire 245). Using vipassana, the Mariner observes the colors of the water snakes and the manner in which they swim. It is important to mention that the Mariner does not judge the water snakes at this moment as he judged the wind, snow, and cliffs earlier in the poem; instead, he simply observes the water snakes without discrimination, and this simple observation allows him to see into the true nature of the water snakes. Contrary to the all-consuming fire that appears after the albatross is killed, the sudden flash of "golden fire" that appears while the Mariner meditates on the water snakes is

\footnotetext{
${ }^{93}$ Vipassana is most often associated with Theravada Buddhism. Vipassana translates to "insight" (Maguire 245).
} 
comparable to the fire described by Nicherin earlier in this chapter: "the fire of enlightened wisdom" (Soka Gakkai International).

That the Mariner achieves a heightened level of wisdom after meditating is suggested by the text, for the Mariner immediately and unexplainably displays a drastic change in his perception of nature:

O happy living things! no tongue Their beauty might declare:

A spring of love gusht from my heart, And I blessed them unaware! Sure my kind saint took pity on me, And I blessed them, unaware. (286-291)

Counter the above excerpt with an earlier passage in the poem where the Mariner reflects on the water snakes:

The men, so beautiful!

And they all dead did lie:

And a thousand thousand slimy things

Lived on; and so did I. (240-243)

Juxtaposing the two passages above, within the first passage there is discernable karuna (compassion), for the Mariner forgets his own misfortune and blesses the water snakes. By blessing the water snakes, the Mariner essentially asks God for their protection and wellbeing - even though at first he was unable to pray to God for his own welfare:

I looked to heaven, and tried to pray;

But or ever a prayer had gusht,

A wicked whisper came, and made

My heart as dry as dust. (248-251)

The immense compassion displayed by the Mariner solidifies his awakening to reality. According to Buddhist philosophy, in order for humans to awaken to reality, they must equally develop compassion and wisdom (Rahula). Within Buddhism terms, karuna 
signifies "love, charity, kindness, [and] tolerance" (Rahula 46). As illustrated through the story of the Buddha, someone who has attained enlightenment is filled with karuna for all living things, and that compassion is expressed through a selfless desire to strive for universal wellbeing. By blessing the water snakes, and not himself, the Mariner displays the ultimate selfless act of love and charity.

Accentuating the Mariner's enlightened state when he blesses the water snakes, the second passage is devoid of compassion for the water snakes. For example, behind the ironic contrast between the picturesque, yet dead shipmates and the slimy, yet alive water snakes is the insinuation that the lives of the shipmates are more valuable than those of the water snakes. The compassionless analogy made by the Mariner suggests that the water snakes should be dead - rather than the shipmates.

In addition to lacking in compassion, the second passage also lacks in prajna, which is displayed through the creation of the 'other' as well as the identification with that 'other.' Through the Mariner's description of the water snakes as grotesque, and the shipmates as beautiful, he once again separates humanity from nature. However, contrary to the previous moments in the poem where the Mariner constructs his own identity through the negation of the 'other,' when the Mariner glares upon the water snakes with disgust, the Mariner constructs the 'other' as hideous and shameful in order to liken himself to it: "And a thousand thousand slimy things / Lived on; and so did I" (240-243). As an 'other,' the Mariner views himself as not being at the same level as humans; ${ }^{94}$

\footnotetext{
${ }^{94}$ The tanha displayed by the Mariner earlier (the desire to exist) is now juxtaposed with the third manifestation of tanha, the desire to destroy. Manifesting the third tanha, the Mariner craves his own destruction, and he identifies himself with the 'other' in order to
} 
instead, he reduces himself to that which he perceives as 'other.' Unaware of his own mind, what the Mariner truly sees as the hideousness of nature is in reality a projection of his own mind. Despite the Mariner's initial ignorance, through the meditative process of vipassana, the Mariner transcends his previously discursive, ego-based perception of the water snakes and himself, for in the second passage he does not identify with the water snakes nor use them as a springboard for constructing his own identity.

In addition to a change in perception, the Mariner's awakening is also reflected in the great joy he feels. As discussed earlier, happiness in Buddhism is correlated with the awakened mind, and Mahakasyapa himself was said to have smiled at the moment he awakened into nirvana. Within the same context, the awakening to what is gives rise to happiness, which coincides with The Third Noble Truth, which teaches that dukkhaalthough it is a part of life, has an end. Instead of discerning the water snakes as hideous, slimy creatures, the Mariner perceives their true Buddha-nature - their already perfect state of being; such a realization brings about joy. Because everything we perceive in the external world is a projection of the mind, the Buddha-nature discerned in others is also the Buddha-nature discerned in the self. The Mariner highlights the correlation between Buddha-nature without and Buddha-nature within by immediately praying after he blesses the water snakes. Whereas previously the Mariner could not conceive of praying because he viewed himself as a lowly, slimy water snake, once the Mariner discerns the true nature of the water snakes, he also discerns his own true nature, which grants him license to pray because he perceives his own internal perfection - his Buddha-nature.

make his own destruction permissible, for the destruction of a human would be wrong according to the Mariner's anthropocentric logic. 
Buddha-nature within and without dissolves the subject-object distinction of the ignorant mind.

As the Mariner continues to observe without the barriers of ego-based thoughts, he suddenly and unexpectedly enters into a meditative dream. Tibetan Buddhists believe in the meditative dream, or "dream yoga, in which awareness is cultivated during lucid dreams" (Keown 92). The lucid nature of the Mariner's dream is conveyed through its pellucid and genuine-to-real-life features, for the Mariner simply dreams of the buckets on board drenched in water:

The silly buckets on the deck, That had so long remained, I dreamt that they were filled with dew; And when I awoke, it rained. (301-304)

After awakening from the dream, the Mariner experiences that which he dreamed - the buckets are filled with water. Because of the prophetic quality of the dream (i.e., he predicts the impending rain within his dream), the Mariner displays an alignment with the natural environment that truly captures the cognitive transformation he has undergone.

The Mariner's journey out of ignorance into enlightenment continues after the yoga dream, where the Mariner enters into a heightened level of consciousness that moves beyond form into formlessness. In a highly conscious state, the Mariner describes himself as unfettered from the physical body:

I moved, and could not feel my limbs:

I was so light - almost I thought I had died in sleep,

And was a blessed ghost. ${ }^{95}(309-312)$

\footnotetext{
95 "The suspended condition of 'half-awake', with the mind floating and planning between the consciousness and unconscious state, always fascinated [Coleridge]" (Holmes 14).
} 
Although the Mariner can sense that he exists - because he is able to move and reflect, he cannot feel any distinguishable body parts. The sensations of formlessness the Mariner describes are significant to a Buddhist reading of the poem because they highlight the Mariner's transformation from a mental state that is unable to look beyond form, to a mental state that so expansive that it is not able to perceive form. With his awakened mind, the Mariner cannot see any physical limitations or demarcations separating the self from the previously discerned other. However, the self-less sensation experienced by the Mariner does not imbue him with fear; instead, he maintains an aura of deep relaxation and calm. Without a self, the Mariner is similar to empty space. According to Keown in Buddhism, the sensations the Mariner experiences are the result of profound meditation:

During the deeper stages of meditation the main bodily functions become subdued, and breathing is all but suspended. Research suggests that the brain generates more alpha-waves in this state, indicating a condition of relaxed creativity. Many unusual sensations may occur: [such as] feeling of floating or lightness of limbs. (Keown 95)

The floating, selfless state described by the Mariner is similar to the Zen concept of sunyata, or emptiness. Buddhist doctrines on emptiness describe the mind as awakening to emptiness. "Rather than being limited to grasping some thing, the mind opens to experience total freedom" (Maguire 78). In the Mahayana and Vajrayana schools of Buddhism, sunyata is "synonymous with nirvana" (Maguire 242), which makes the Mariner's experience with sunyata indicative of his enlightenment.

Moving beyond the meditative states achieved by the Mariner, it is not until readers remember (or revisit) the beginning of the poem that they gain the full scope of the Mariner's enlightenment. Although the Mariner's awakening to reality would posit 
him as a Buddha, readers do not see many clues within the Mariner's story that truly hint at an awakening to nirvana. However, there is evidence at the beginning of the poem that suggests that the Mariner is a Buddha.

One such proof lies in the Mariner's visage, for it is his connection to Buddhism that gives him his odd appearance, and it is his notable mien that arouses fear in the wedding guest - who seems to have never encountered a traveling Buddha before: "I fear thy skinny hand! / And thou art long, and lank, and brown, / As is the ribbed sea-sand" (228-231). From the Mariner's physical portrayal, it appears as though he has been traveling for a substantial amount of time - at least long enough for his body to grow thin and his skin to become darkened from the sun. ${ }^{96}$ The correlation made here between the Mariner's appearance and the trampled, dry sand of the beach is telling, for it highlights the Mariner's fixed determination. The Mariner's "long grey beard" (3), in conjunction with his weathered skin, is evidence of his long spiritual journey. Despite the discomforts an elderly, weather-beaten, hungry body might produce, the Mariner continues to travel in order to tell his story: "And till my ghastly tale is told, / This heart within me burns. / I pass, like night, from land to land; / I have strange power of speech" (587-591).

Like the Mariner, the Buddha "was originally a wandering teacher" (Keown 11) who "traveled over a large area spreading his teachings, and explicitly charged his disciples to do likewise with the words: 'Go, monks, and wander for the good and welfare of the multitudes"” (Keown 73). With years of traveling and teaching, many of

\footnotetext{
${ }^{96}$ The majority of the physical descriptions given of the Mariner point to a nomadic traveler. These descriptions are given numerous times throughout the poem, which indicate there is a symbolic significance to the weathered visage.
} 
the itinerant monks of early Buddhism would have encountered hunger and physical hardships in their efforts to spread the dharma. ${ }^{97}$ Symbolic of the Buddhist traveling tradition, the Mariner's aim is a selfless one that is highlighted by his unrelenting compassion and desire to spread his story far and wide, which not anything - not even poor physical conditions - can abate.

The "skinny" (228) demeanor of the Mariner, which is often alluded to by the wedding guest, also ties the Mariner to the Buddha through the begging-for-alms tradition of Buddhism - where the monks go out into the community and beg for food once a day. ${ }^{98}$ The begging tradition is an essential aspect of Buddhist monastic life, and the Buddha himself begged for food daily - not only for the alms, but for the opportunity to spread the teachings as well. As part of the tradition, some monks - depending on the sect of Buddhism - offer sutras ${ }^{99}$ in exchange for the food they receive. The presence of the Mariner in a location where a wedding is occurring places him in the midst of not only a feast - a place where he is sure to receive alms for his teaching, but also in the vicinity of many possible students. With the Buddhist begging-for-alms tradition in mind, perhaps it is not a coincidence that the gloss describes the Mariner as arriving just when the "three Gallants [are] bidden to a wedding-feast" (6). Although the narrator does not indicate if the Mariner receives alms before or after his teaching, the Mariner's presence

${ }^{97}$ As mentioned in Chapter 1, dharma has several definitions depending on the context in which it is used. Within the context of spreading dharma, I am referring to the Buddha's teachings (reality itself).

${ }^{98}$ These monks eat only once a day, and they do not beg for more than what they need at that moment. Consequently, many Buddhist monks tend to be thin.

${ }^{99}$ Buddha discourses. 
during a feast - especially at the exact moment when the feast is served - gives way to the possibility of a link between the Mariner's arrival and the presence of the food. Interestingly, the Mariner departs after the feast.

More significantly, a bell is rung when the Mariner enters and begins his story and when he departs at the ending of his story. Soon after the Mariner stops one of the wedding guests, the thwarted wedding guest states: "the feast is set: / May'st hear the merry din" (7-8). The sound heard once the table is set can be interpreted as the ringing of a dinner bell. When the Mariner exists, the "vesper bell" (599) calls the guests to "prayer" (600). The presence of a bell is noteworthy within a Buddhist context because several Buddhist deities are portrayed with a bell in their hand, such as Vajradhara and Vajrasattva (Blau 235). Within Buddhism, the bell symbolizes wisdom, nirvana, and "the comprehension of emptiness ${ }^{100}$ in all its forms" (Blau 235). When rung, the bell pulls the mind from discursive thoughts and brings it to the emptiness of the present and eternal now. Contrary to the Mariner at the beginning of the poem, who could not see beyond form into emptiness, the sounding of the bell at the moment the Mariner enters suggests that the Mariner has grasped the unifying truth of emptiness. The Mariner's tale stresses a message similar to that conveyed by the symbolic bell - the importance of transcending the discursive, ignorant mind. As a representation of wisdom, the bell - in conjunction with the Mariner's presence and departure - solidifies the Mariner as a Buddha who has come to impart his wisdom to others.

\footnotetext{
${ }^{100}$ Emptiness, or sunyata, refers to "the impermanent, nonessential, interdependent nature of all things, so that no one thing exists in itself" (Maguire 242).
} 
As a Buddha, the Mariner is human, and yet he also possesses a superhuman quality that separates him from an unenlightened, or unawakened, being. That Siddhartha was an ordinary person of flesh and bones is an important feature of the Buddha story that brings to the forefront the message that anyone can become a Buddha, and anyone can awaken to reality (Grubin). Despite his corporeal frame, the Buddha also "came to be thought of as a semi-divine being" "101 (Keown 61). Several stories of the Buddha highlight his superhuman quality. ${ }^{102}$ Sensing the aura of divinity that surrounds the Mariner, the wedding guest often raises doubts regarding the Mariner's human status: "II fear thee, ancient Mariner! [...] / I fear thee and thy glittering eye"” (228-232). The Mariner responds by ensuring the wedding guest of his mortality: "Fear not, fear not, thou Wedding-Guest! / This body dropt not down" (234-235). Supporting the Mariner's statement, the gloss reads: "But the ancient Mariner assureth him of his bodily life" (38). However, the narrator's decision to refer to the Mariner as an "IT"103 (1) forces readers to reject the possibility that the Mariner is on the same earthly level as the wedding guest; the narrator seems bent in making such a point, as "IT" is not only written in all capital

\footnotetext{
101 The Buddha "did not claim to be other than a human being [...]. He claimed no inspiration from any god or external power either. He attributed all his realization, attainments and achievements to human endeavor and human intelligence" (Rahula 1). However, "he was so perfect in his 'human-ness' that he came to be regarded later in popular religion almost as "super-human"” (Rahula 1).

102 Such as the story involving Devadatta's attempts to kill the Buddha. For more examples of the Buddha's superhuman abilities, see Reginald A. Ray's Buddhist Saints in India.

103 The line reads: "IT is an ancient Mariner" (1).
} 
letters, it is also the very first word in part 1 of the poem, which forces readers to pay attention to "IT."

What is suggestive about the wedding guest's fear toward "IT" is that he initially attributes the Mariner's otherworldliness to something he perceives within the Mariner's "eye" (232). It is worth noting that the wedding guest does not use the plural form here eyes. Instead, he refers to the Mariner's eyes in the singular form several times throughout the poem. ${ }^{104}$ For example, the gloss states: "The Wedding-Guest is spellbound by the eye of the old seafaring man" (8). Expressions involving the eye in singular form are often used in Buddhist texts "referring to persons who realized Truth [such as]: "The dustless and stainless Eye of Truth [...] has arisen"” (qtd. in Rahula 9) and "“the eye was born, knowledge was born, wisdom was born, science was born, light was born"”105 (qtd. in Rahula 9). The significance of the eye in the above expressions lies within the concept of "the all seeing eye" (Deegalle 26) that has transcended all delusions, and is thus able to see all things as they truly are. The all-seeing eye plays a special role in Buddhism, and it is referred to as the Buddha Eye. ${ }^{106}$

That the Mariner possesses the Buddha Eye is evident on account of both its description and its abilities. First, the wedding guest's description of the Mariner's eye

${ }^{104}$ In the singular form, "eye" is mentioned twelve times in the 1817 edition of the poem. ${ }^{105}$ In "reference to his own enlightenment," the Buddha is said to have uttered the above words (qtd. in Rahula 9).

${ }^{106}$ There are five different types of "noncorporeal eyes" (Epstein 81) possessed by the Buddha: Physical Eye, Heavenly Eye, Wisdom Eye, Dharma Eye, and Buddha Eye (Hua 8). For a thorough explanation on the differences between the corporeal eyes of the Buddha, see Hsuan Hua's The Buddha Speaks of Amitabha Sutra: A General Explanation and Ronald B. Epstein's Buddhism A to Z. 
mimics the description of the Buddha Eye found in a Mahayana sutra. Describing the different corporeal eyes of the Buddha, the verse reads: "The Heavenly Eye penetrates without obstruction. The Flesh Eye sees obstacles but does not penetrate. The Dharma Eye only contemplates the mundane. The Wisdom Eye understands True Emptiness. The Buddha Eye shines like a thousand suns" (qtd. in Hua 8). Comparable to the Buddha Eye, which "shines like a thousand suns" (Hua 8), the Mariner's eye is often described as "bright" 107 and "glittering"108 - characteristics which are often used to illustrate the sun. ${ }^{109}$ Further connecting the Mariner's Buddha Eye with the image of the sun, the words "bright" are used twice throughout the poem to describe the actual sun: "The Sun came up upon the left, / Out of the sea came he! / And he shone bright, and on the right / Went down into the sea" (25-28); "Almost upon the western wave / Rested the broad bright Sun" (173-174). By using the same words to describe these seemingly disparate things, the narrator unites them in a profound manner that illuminates the Mariner as a Buddha. Contrary to the sad demeanor of the Mariner at the beginning of his tale, the glittering and bright appearance of the Mariner's eye implies that he is happy. The

${ }^{107}$ The lines read: "And thus spake on that ancient man, / The bright-eyed Mariner" (1920); "The bright-eyed Mariner" (40); "His great bright eye most silently / Up to the Moon is cast" (420-421); and "The Mariner, whose eye is bright" (631). The 1798 edition of the poem possesses an interesting verse related to the eye: "Listen, O listen thou Wedding-guest! / 'Mariner, thou hast thy will: / For that, which comes out of thine eye, doth make / My body and soul to still'" (371-375).

${ }^{108}$ The lines read: "By thy long grey beard and glittering eye" (3); "I fear thee and thy glittering eye" (233).

${ }^{109}$ The connection between the Buddha Eye and the sun is made in Natale's The One Life. See Chapter 2. 
glittering eye of the Mariner, as a representation of his happiness, is akin to the smile conveyed by Buddha deities and enlightened beings.

In addition to possessing the physical attributes of the Buddha Eye, the Mariner's eye is coupled with the Buddha Eye through its omnipotent capabilities. The Mariner unveils the exceptional power behind his Buddha Eye when he apprehends the wedding guest with just his gaze:

He holds him with his skinny hand, 'There was a ship,' quoth he, 'Hold off! unhand me, grey-beard loon!'

Eftsoons his hand dropt he.

He holds him with his glittering eye The wedding-guest stood still, And listens like a three years child:

The Mariner hath his will.

The wedding-guest sat on a stone:

He can not chuse but hear;

And thus spake on that ancient man, The bright-eyed mariner. (9-20)

Unable to physically arrest the resisting wedding guest with his "skinny," (9) emaciated frame, the Mariner's hand "dropt" (12); the symbolic gesture emphasizes the physical limitations of the Mariner's body, particularly when juxtaposed with the wedding guest's ability to resist. ${ }^{110}$ Despite his physical superiority, the wedding guest is defenselessly subdued once the Mariner abandons all physical attempts at restraint and stares at him with his "glittering eye" (13). Against his will, the wedding guest is held captive by the Buddha Eye; suddenly he is constrained to sit on a stone despite his previous attempts to

${ }^{110}$ The 1798 edition of the poem accentuates these contraries even more by having the wedding guest physically threaten the Mariner: "Now get thee hence, / thou grey-beard Loon! / Or my Staff shall make thee skip" (15-16). The 1798 verse works to emphasize the wedding guest's initial dominance. 
leave. The lowered, sitting position - while the Mariner stands over the wedding guest signifies the wedding guest's powerlessness and submissiveness in the face of the Mariner's Buddha Eye. In spite of his desire to attend the wedding, the wedding guest is powerless to do anything but listen:

The bride hath paced into the hall, Red as a rose is she; Nodding their heads before her goes The merry minstrelsy.

The Wedding-Guest he beat his breast, Yet he can not chuse but hear; And thus spake on that ancient man, The bright-eyed Mariner. (33-40)

The violent act of beating his chest highlights the wedding guest's eagerness to leave the Mariner and attend the wedding, as well as his utter inability to do so as a result of the Mariner's powerful Buddha Eye.

In conjunction with the image of the all-seeing eye, the Mariner's omnipotence is further conveyed when the Mariner singles out the wedding guest. It is important to mention here that the all-seeing eye of the Buddha is also said to possess psychic abilities (Deegalle), and consequently, the Buddha was believed to possess the capability of looking at a group of individuals and discerning who was most in need of his teachings:

[...] by means of the Buddha-eye, the Buddha recognized the psychological nature of his subjects, that is, whether they were greedy, hateful, dull, ruminating, faithful, or intelligent. Several canonical texts also state that it is with the Buddha-eye that the Buddha saw beings whose minds were "little defiled or much defiled, $[\ldots]$ beings of good disposition and of evil disposition, beings who can be easily convinced and those who can be convinced with difficulty.' These scriptural references demonstrate why early Buddhists believed that the Buddha-eye was crucial to the Buddha's success as a preacher. (qtd. in Deegalle 26) 
Displaying a similar level of omnipotence, the Mariner instinctively knows which wedding guest to stop: "IT is an ancient Mariner, / And he stoppeth one of three" (1-2). In mentioning the all-seeing eye, the wedding guest's response eliminates the likelihood that the Mariner stopped that particular guest at random: "By thy long grey beard and glittering eye, / Now wherefore stopp'st thou me?" (3-4). Although the narrator does not explain why the Mariner stops one particular guest and not another, the Mariner does imply that he recognized, with his all-seeing eye, that a specific wedding guest needed to hear his story: "That moment that his face I see, / I know the man that must hear me: / To him my tale I teach" (591-594). That the Mariner possesses the ability to "see" who is in need of his teaching is validated at the end of the poem when the wedding guest is described as being sadder, yet wiser, after having heard the Mariner's story: "He went like one that hath been stunned, / And is of sense forlorn: / A sadder and a wiser man, / He rose the morrow morn" (626-629). The word "wiser" implies that the wedding guest was ignorant prior to hearing the Buddha Mariner's story, and consequently, the Mariner chose the appropriate wedding guest to enlighten with his tale.

Although readers do not know what specific aspect of the Mariner's tale caused the wedding guest to feel unhappy, the sadness expressed by the wedding guest connects him to the story of Siddhartha. After learning that life is full of suffering, Siddhartha felt an overwhelming, yet compassionate sadness; this sadness came as a result of knowledge, which led Siddhartha to seek a path toward ending suffering for all beings. Although Siddhartha had not yet reached full enlightenment, the sadness he experienced points at the beginning of the awakening process. Within the same vein, the wedding guest's sadness indicates the beginning of his own enlightenment. Further identifying the 
Mariner as a Buddha through his teaching of the wedding guest, Dogen in Genjo Koan describes a Buddha as someone who aids other people in awakening to their Buddhanature: "When buddhas are truly buddhas they do not necessarily notice that they are buddhas. However, they are actualized buddhas, who go on actualizing buddhas" (qtd. in Rudy 137). Although readers are not told what the wedding guest does with his newfound knowledge, it is interesting to postulate that the wedding guest manifests this knowledge into something positive, and perhaps he, too, eventually becomes a Buddha as a result of the Mariner's didactic tale.

As a result of being able to perceive the psychological states of those around him, the Buddha was believed to possess the ability to tweak his teachings according to the particular needs of his listeners. According to Deegalle in Popularizing Buddhism:

In religious instruction, the Buddha-eye proved useful in determining the course of advice appropriate to the character and intellectual capacity of the individuals receiving the Buddha's guidance. It is suggested in the early Pali texts that the Buddha was successful as a preacher because he could read the minds of his audience. Through thought reading, he was able to know their spiritual propensities and could in turn assign an appropriate meditation device or preach an attention-getting sermon. (26)

In accordance with Deegalle's description of the Buddha Eye's abilities, the Buddha Mariner does offer an "attention-getting sermon" that not only captures the wedding guest, but also alters his perception of the world; in order to create such a sermon, the Mariner must have been able to "see" within the wedding guest in order to offer the most effective teaching. Since it has been confirmed by the Mariner's appearance that he has been traveling for a significant amount of time, it can be assumed that he would have come upon more than one person to unveil his tale to; it would be interesting to surmise 
that the Buddha Mariner alters his story every time he tells it in order to suit the needs and preferences of a particular listener.

Working within the same vein, the many editions of The Rime of the Ancient Mariner would not oppose one another despite their differences. Instead, they would serve as a heterogeneous sample of the ways in which the Buddha Mariner has re-told the general story in order to reach and enlighten diverse groups of listeners. For example, the 1798 edition from Lyrical Ballads states that "The strong wind reach'd the ship: it roar'd / And dropp'd down, like a stone!" (329-330). In the 1798 version of the poem, it is the wind that naturally moves the ship along. There is nothing odd or frightening about what occurs, and thus, a listener of the 1798 version of the poem would not pay too much attention to the minor detail involving the wind and the ship; it is also likely that the listener of the 1798 version of the tale would be less inclined toward the mystical. In the 1817 edition, the same moment from above is imbued with supernatural qualities: "The loud wind never reached the ship, / Yet now the ship moved on!” (331-332). The 1817 version of the poem displays a ship that is not moved by the wind, but by some other unforeseen force. Because the excerpt from the 1817 edition focuses on something that goes against the laws of nature, it is likely that the listener of the eerie 1817 version of the poem would possess the ability to suspend disbelief in the supernatural. Although all the editions of The Rime of the Ancient Mariner communicate the same central plot, there are subtle differences that might appeal more to a certain listener depending on religious beliefs or personal mindsets. In congruence with the above argument, Coleridge himself also compulsively revised The Rime of the Ancient Mariner several times throughout his 
lifetime; in English Romantic Irony, Mellor speculates that Coleridge's desire to please his audience - and possible benefactors - was the motivation behind his many revisions.

Regardless of the version told, the Buddha Mariner's overall story serves a didactic purpose, which is to enlighten. The Mariner's aim places him in the role of a spiritual teacher - just like the Buddha. The Mariner confirms his unique role, for he does not simply portray himself as having to tell a story, but rather, as having to "teach" (594) a story. That the poem is meant to instruct is supported by the description given of the wedding guest, who "listens like a three years child" (13-16) - a comparison which likens the wedding guest to a pupil receiving a lesson. Similarly to the Buddha, and contrary to Christian motifs, the Mariner is not taught what he learns; instead, he discovers it for himself. Moreover, God does not save the Mariner, but rather, the Mariner saves himself. The idea of achieving enlightenment on one's own is important to the story of the Buddha, for the Buddha "claimed no inspiration from any god or external power either. He attributed all his realization, attainments and achievements to human endeavor and human intelligence" (Rahula 1). Similarly, in his teachings, the Mariner does not use the words or experiences of another sage, but rather, he pulls from his own personal experiences. The gloss fosters such an assertion by stating: "And to teach, by his own example, love and reverence to all things [...]" (91). By using his own private story as a means to teach, the Mariner goes about teaching much in the same way as the Buddha did, for "the Buddha's personal experience of enlightenment is the bedrock of the entire Buddhist tradition. Time and again he invoked his own experience as authority for his doctrines, and suggested that teachings not validated by personal experience were of little value" (Keown 7). 
Lastly, the stories of the Buddha and the Mariner possess similar themes, such as ending universal suffering, the importance of transcending ignorance, and using meditation as a tool to awaken to reality. Motivated by compassion, the Buddha tells his story in order to bring an end to universal dukkha: "The Buddha stated, 'Both in the past and now, I set forth only this: suffering and the end of suffering"' (Keown 46). Similarly to the message taught by the Buddha, the Mariner's story is focused on the suffering that occurs, for sentient and insentient beings, when ignorance is present. In order to transcend ignorance, both figures stress the importance of prajna. Siddhartha's journey to uncover the knowledge that will end universal suffering highlights the focus Buddhism places on prajna. Although the significance of cultivating prajna is emphasized throughout The Rime of the Ancient Mariner, it is most blatantly stressed in the exert from Thomas Burnet's Archaeologiae Philosohicae, which Coleridge inserted into the beginning of the 1817 edition of the poem: “[ ...] we must be vigilant for the truth and keep due proportion, so that we may distinguish the certain from the uncertain [...]" (5). What aids the Mariner in distinguishing the truth from the untruth is meditation. Buddhism places great importance on meditation, which is highlighted in the Buddha's awakening after a moment of intense meditation under a Bodhi tree. Buddhists pay homage to this meaningful moment in Siddhartha's journey by portraying him in the lotus meditation position. By highlighting meditation as a means to transcend ignorance, the Buddha's story functions as a detailed plan for others who wish to achieve enlightenment. By focusing on meditation, the mariner's story also works as a road map for how the development of prajna through meditation can be used as a tool to avoid suffering for "all things both great and small" (619). 
Although the Mariner has not been usually perceived within the framework of Buddhism, the Mariner-as-Buddha analogy provides a new angle from which to analyze the major changes the Mariner undergoes in the poem. Bringing that transformation to the forefront, it is undeniable that the Mariner's story is a journey from ignorance to wisdom - regardless of what lens the poem is held under. Because the Buddha's cognitive transformation is at the core of his teachings, the fact that the Mariner's evolution is what anchors his didactic story makes the amalgamation of these figures a logical endeavor; and The Rime of the Ancient Mariner lends itself well to a Buddhist interpretation. Within the context of Buddhism, the Mariner begins the story as an ignorant being that suffers because he is unable to see the true nature of things. Believing in the delusion created by the unawakened mind, the Mariner acts against nature in an effort to aggrandize the illusory 'I,' which brings him additional suffering - as well as suffering to all sentient and non-sentient beings. It is not until the Mariner meditates and dissolves the discursive mind that he is able to awaken to what is and become a Buddha; as a Buddha, he shares his story in an effort to end universal suffering. In a sense, because his actions have such a huge impact on the earth, the Mariner decides the fate of the world. With his sutra, the Mariner teaches every being - and all readers - that they, too, have the ability to become enlightened and decide the fate of the world by ending universal dukkha. 


\section{REFERENCES}

Abe, Masao. A Study of Dogen: His Philosophy and Religion. Ed. Steven Heine. New York: State University of New York Press, 1992. Print.

Abrams, M.H. The Norton Anthology of English Literature. Ed. 7, Vol. 2. W.W. Norton \& Company, 2000. Print.

Armbruster, Karla M., and Kathleen R. Wallace, eds. Beyond Nature Writing:

Expanding the Boundaries of Ecocriticism. University of Virginia Press, 2001. Print.

Ashliman, D.L. "The Jataka Tales." University of Pittsburgh, 2002. Web. 20 Dec. 2013. < http://www.pitt.edu/ dash/jataka.html>

Babbitt, Ellen C. More Jataka Tales. Kessinger Publishing, 2004. Print.

Bate, Jonathan. The Song of the Earth. Harvard University Press, 2002. Print.

Beer, John, ed. Coleridge's Writings. Basingstoke, 1990. Print.

Benton, Richard P. "Keats and Zen." Philosophy East and West. Vol. 16, No. 1 (Jan. April 1966): 33-47. JSTOR. Web. 27 Oct. 2010.

Blau, Tatjana and Mirabai Blau. Buddhist Symbols. NY: Sterling Publishing Co., Inc., 2003. Print.

Bly, Robert. News of the Universe: Poems of Twofold Consciousness. Sierra Club Books, 1980. Print.

Blyth, R.H. Zen in English Literature and Oriental Classics. Tokyo: The Hokuseido Press, 1942. Print.

Britto, John M. "An Ecocritical Reading of William Wordsworth's 'Tintern Abbey.'” Academic Research International. Vol. 2, No. 1 (January 2012): 720-725. Web. 15 Feb. 2012.

Coffman, Ralph. Coleridge's Library: A Bibliography of Books Owned or Read by Samuel Taylor Coleridge. Boston, 1987. Print

Coleridge, Samuel Taylor. The Annotated Ancient Mariner. Ed. Martin Gardner. Prometheus Books, 2003. Print. 
---. Biographia Literaria; or, Biographical Sketches of My Literary Life and Opinions. Eds. James Engell and W. Jackson Bate. Princeton University Press, 1984. Print.

---. Biographia Literaria; or, Biographical Sketches of My Literary Life and Opinions. Vol. 1. Ed. J. Shawcross. Oxford University Press, 1962. Print.

---. Biographia Literaria; or, Biographical Sketches of My Literary Life and Opinions. Vol. 2. Ed. J. Shawcross. Oxford University Press, 1969. Print.

---. Coleridge's Ancient Mariner: An Experimental Edition of Texts and Revisions 17981828. Ed. Martin Wallen. Barrytown, N.Y.: Station Hill, 1993. Print.

---. Coleridge: The Early Family Letters. Ed. James Engell. Oxford University Press, 1995. Print.

---. Coleridge's Poetry and Prose. Ed. Nicholas Halmi, Paul Magnuson, and Raimonda Modiano. W.W. Norton \& Company, Inc., 2004. Print.

---. "The Dialectic of Mind and Nature." The Green Studies Reader: From Romanticism to Ecocriticism. Ed. Laurence Coupe. London, England: Routledge, 2000. Print.

---. "Kubla Khan: or a Vision in a Dream." Coleridge's Poetry and Prose. Ed. Nicholas Halmi, Paul Magnuson, and Raimonda Modiano. W.W. Norton \& Company, Inc., 2004. Print.

---. "Kubla Khan: or a Vision in a Dream." The Norton Anthology of English Literature. Ed. 7, Vol. 2. Ed. Abrams, M.H. W.W. Norton \& Company, Inc., 2000. Print.

---. On the Constitution of the Church and State. Ed. John A. Colmer. Princeton University Press, 1977. Print.

---. "The Rime of the Ancient Mariner." The Rime of the Ancient Mariner: Case Studies in Contemporary Criticism. Ed. Paul H. Fry. Boston, Massachusetts: St. Martin's, 1999. Print.

Coupe, Laurence, ed. The Green Studies Reader: From Romanticism to Ecocriticism. London, England: Routledge, 2000. Print.

Davids, Rhys T.W. Buddhism Birth: Stories (Jataka Tales) of the Life and Teachings of Gautama the Buddha. Laurier Books Ltd., 1999. Print.

Deegalle, Mahinda. Popularizing Buddhism: Preaching As Performance in Sri Lanka. State University of New York Press, 2007. Print. 
Dhammananda, K. Sri. "What Buddhists Believe: The Moon and Religious Observances." Buddhist Study and Practice Group. State University of New York at Stony Brook. Web. 6 Jun. 2012.

Dhammika, S. "Footpoints in the Dust: Buddha's Travels in India." The Island, Sri Lanka. BuddhaSasana, 2002. Web. 18 Dec. 2012.

Dogen. The True Dharma Eye: Zen Master Dogen's Three Hundred Koans. Trans. John Daido Loori and Kazuaki Tanahashi. Shambhala Publications, 2009. Print.

Drew, John. India and the Romantic Imagination. Oxford University Press, 1987. Print.

Encyclopedia Britannica. “St. Elmo's Fire.” Encyclopedia Britannica, Inc., 2013. Web. 15 March 2012.

Engell, James, ed. Coleridge: The Early Family Letters. Oxford University Press, 1995. Print.

Epstein, Ronald B. Buddhism A to Z. Buddhist Text Translation Society, 2003. Web. 10 Jan. 2013.

Estok, Simon C. "Discourses of Nation, National Ecopoetics, and Ecocriticism in the Face of the US: Canada and Korea as Case Studies." Comparative American Studies. Vol. 7, No. (June 2009): 85-97. Web. 2 Feb. 2012.

Fry, Paul H., ed. "Biographical and Historical Contexts." The Rime of the Ancient Mariner: Case Studies in Contemporary Criticism. Boston, Massachusetts: St. Martin's, 1999. Print.

Gach, Gary. The Complete Idiot's Guide to Buddhism. $3^{\text {rd }}$ ed. Alpha, 2009. Print.

Genesis. The Holy Bible: King James Version, 2000. Bartleby.com. Web. 12 March 2013. <http://www.bartleby.com/108/01/9.html>.

Glotfelty, Cheryll, and Harold Fromm, eds. The Ecocriticism Reader: Landmarks in Literary Ecology. University of Georgia Press, 1996. Print.

Gombrich, Richard. What the Buddha Thought. Equinox Publishing, 2009. Print.

Griggs, Earl Leslie, ed. Collected Letters of Samuel Taylor Coleridge, Vol. 1. Oxford, Clarendon Press, 2000. Print.

Grubin, David, dir. The Buddha: The Story of Siddhartha. Perf. Richard Gere. PBS, 2010. DVD. 
Harrison, Paul A. Elements of Pantheism: Religious Reverence of Nature and the Universe. $2^{\text {nd }}$ ed. Coral Springs, FL: Llumina Press, 2004. Print.

Holmes, Richard. Coleridge: Early Visions, 1772-1804. New York: Viking, 1989. Print.

---. Coleridge: Darker Reflections, 1804-1834. Pantheon, 2000. Print.

Hua, Hsuan. The Buddha Speaks of Amitabha Sutra: A General Explanation. Buddhist Text Translation Society, 2003. Web. 1 Jan. 2013.

Huntington, John C. and Dina Bangdel. The Circle of Bliss: Buddhist Meditational Art. Serindia Publications, 2003. Web. 9 June 2013.

Huntington, Susan L. The "Pala-Sena" Schools of Sculpture (Studies in South Asian Culture, Vol 10). Humanities Press, 1984. Web. 21 Dec. 2012.

Irwin, Robert. The Arabian Nights: A Companion. Tauris Parke Paperbacks, 2004. Print.

Jarrett-Kerr, Martin. "Indian Religion in English Literature 1675-1967." Essays and Studies 37. (1984): 87-103. MLA International Bibliography. EBSCO. Web. 21 May 2011.

Johnson, Kurt Andrew. "Sir William Jones and Representations of Hinduism in British Poetry, 1784 - 1812.” Diss. University of York, 2010. Web. 20 Jan. 2012.

Keown, Damien. Buddhism: A Very Short Introduction. Oxford University Press, 1996. Print.

Kinnard, Jacob. The Emergence of Buddhism. Westport, Conn.: Greenwood Press, 2006. Print.

Kristeva, Julia. "From Revolution in Poetic Language." The Norton Anthology of Theory and Criticism. Ed. Leitch. W.W. Norton \& Company, Inc. 2001. 2169-2179. Print.

Lowes, John Livingston. The Road to Xanadu. Princeton University Press, 1986. Print.

Lussier, Mark S. Romantic Dharma: The Emergence of Buddhism into NineteenthCentury Europe. New York: Palgrave, 2011. Print.

---. Romanticism and Buddhism. College Park, MD: University of Maryland, 2007. MLA International Bibliography. EBSCO. Web. 21 May 2011. 
Maguire, Jack. Essential Buddhism: A Complete Guide to Beliefs and Practices. NY, NY:Pocket Books, 2001. Print.

Marzolph, Ulrich, Richard Van Leeuwen, and Hassan Wassouf. The Arabian Nights: An Encyclopedia, Vol. 1. ABC-CLIO, 2004. Print.

Mays, J.C.C. The Collected Works of Samuel Taylor Coleridge: Vol. 16. Poetical Works: Part 1. Poems (Reading Text). Princeton University Press, 2001. Web. 20 Dec. 2012.

Mazumder, Aparajita. "Coleridge, Vishnu, and the Infinite." Comparative Literature Studies 30.1 (1993): 32-52. MLA International Bibliography. EBSCO. Web. 21 May 2011.

McFarlane, Thomas. Coleridge and the Pantheist Tradition. Oxford University Press, 1969. Print.

Mellor, Anne K. English Romantic Irony. Cambridge, Mass.: Harvard University Press, 1980. Print.

Morton, Timothy. The Ecological Thought. Harvard University Press, 2010. Print.

---. Ecology Without Nature. Harvard University Press, 2009. Print.

Moser, Paul K., and J.D. Trout, eds. Contemporary Materialism: A Reader. Routledge, 1995. Web. 20 Jan. 2012.

Mueller, Friedrich Max, ed. Dhammapada: The Teachings of the Buddha. Fall River Press, 2009. Print.

Muirhead, John H. Coleridge as Philosopher. New York: Humanities Press, 1954. Print.

Murfin, Ross C. "Psychoanalytic Criticism and Hamlet." Hamlet: Case Studies in Contemporary Criticism. Ed. Susanne L. Wofford. Boston: Bedford Books of St. Martin's Press, 1994. Print.

Natale, Antonella Riem. The One Life: Coleridge and Hinduism. Jaipur, India: Rawat Publications, 2005. Print.

Nelson, Walter. Buddha: His Life and His Teaching. Penguin Group, 2008. Web. 15 June 2012.

New World Encyclopedia. “Koan.” New World Encyclopedia, 2008. Web. 12 March 2013. 
Perkins, David. Romanticism and Animal Rights. Cambridge University Press, 2003. Print.

Rahula, Walpola. What the Buddha Taught. New York: Grove Press, 1974. Print.

Rawlinson, H.G. Narratives from Purchas His Pilgrimes. Cambridge: The University Press, 1931. Print.

Ray, Reginald A. Buddhist Saints in India: A Study in Buddhist Values and Orientations. Oxford University Press, 1999. Web. 11 Jan. 2012.

Rossabi, Morris. Khubilai Khan: His Life and Times. Berkeley: University of California Press, 1988. Print.

Rudy, John G. Romanticism and Zen Buddhism. Lewiston, NY: The Edwin Mellen Press, 2004. Print.

---. Wordsworth and the Zen Mind: The Poetry of Self-Emptying. Albany: State University of New York Press, 1996. Print.

Sadasivan, S.N. A History of India. APH Pub. Corp, 2000. Web. 9 June 2013.

Schwab, Raymond. "The Asiatic Society of Calcutta." Orientalism: A Reader. Ed. Alexander Lyon Macfie. NYU Press, 2001. Print.

Skilton, Andrew. A Concise History of Buddhism. Barnes and Noble, 2003. Print.

Soka Gakkai International. "Desires and Enlightenment." SGI Quaterly, 2013. Web. 9 June 2013.

Suzuki, Daisetz Teitaro. Lankavatara Sutra: A Mahayana Text. Motilal Banarsidass, 2009. Web. 20 Dec. 2012.

Thera, Nanamoli, trans. "Adittapanyaya Sutta: The Fire Sermon.” Accesstoinsight.org. Buddhist Publication Society, 1981. Web. 10 March. 2012.

Tolle, Eckhart. A New Earth: Awakening to Your Life's Purpose. Plume, 2005. Print.

Upadhaya, Kashi Nath. Early Buddhism and the Bhagavadgita. Motilal Banarsidass, 2008. Print.

Waddell, Laurence Austine. The Aryan Origin of the Alphabet. Martino Fine Book, 2010. Print. 
Weissman, Stephen. His Brother's Keeper: A Psychobiography of Samuel Taylor Coleridge. Madison, Conn.: International Universities Press, 1989. Print.

Wordsworth, William. "The Prelude." The Poetical Works of Wordsworth (Cambridge Editions). Houghton Mifflin Company, 1982. Print.

York, Michael. Pagan Theology: Paganism as a World Religion. NYU Press, 2005. Print. 